\title{
THE INTEREST RATE AND CREDIT CHANNELS IN \\ BELGIUM: AN INVESTIGATION WITH MICRO-LEVEL FIRM DATA
}

November 2001

Paul Butzen*, Catherine Fuss" and Philip Vermeulen**

* National Bank of Belgium, boulevard de Berlaimont 5, B-1000 Brussels,Belgium.

E-mail: paul.butzen@nbb.be and catherine.fuss@nbb.be

** European Central Bank, Kaiserstrasse 29, G-60311 Frankfurt, Germany.

E-mail: philip.vermeulen@ecb.int

We would like to thank participants in the Monetary Transmission Network for helpful comments and suggestions.

The views expressed in this paper reflect only the views of the authors. They do not necessarily reflect the views of the European Central Bank, or of the National Bank of Belgium. 


\begin{abstract}
This paper investigates the effects of monetary policy on firms' investment behaviour. The analysis relies on a comprehensive database of Belgian firms covering all sectors of economic activity and firms of all sizes. We proceed in two steps. First, we estimate a reduced-form investment equation derived from the neo-classical model, augmented by cash flow. This equation is estimated by the Arellano and Bond (1991) GMM procedure. Second, we compute the elasticity of the user cost of capital and the cash flow/capital ratio to the policy-controlled interest rate. We estimate the model for various sample splits according to sectors and sizes. Our results indicate that small firms are more sensitive to monetary policy than large firms, and that services are almost unaffected. Since the impact differs across sectors and sizes, we can conclude that monetary policy produces distributional effects.
\end{abstract}

JEL Classification: C23, D21, E50

Key Words: Investment, Monetary transmission, Credit channel, Panel data 


\section{Non-technical summary}

This paper analyses two monetary transmission channels which operate through firms' investment decisions. First, through the interest rate channel, monetary policy affects investment through a change in the user cost of capital. Second, through the credit channel, monetary policy affects the access of firms to internal and external finance and the cost this entails. In a world of asymmetric information between firms and lenders, firms have to pay an external finance premium which depends on their balance sheet position, or rely on internal resources. A monetary policy tightening raises interest rates, thus reducing firms' profits and the value of capital assets that might be used as collateral to obtain new loans. Therefore, it increases the external finance premium. Further, higher interest charges reduce the cash flow, i.e. the internal resources available. Consequently, a monetary policy tightening may raise the degree of financial constraints faced by the firms.

These two channels are assessed for the whole set of Belgian firms over the period 19851998. The time span of the data set has allowed us to analyse the dynamic behaviour of firms' investment, which is per se a dynamic process. Since we have considered the entire panel of Belgian firms, we have examined the behaviour of firms' investments at the microeconomic rather than at the aggregate level. Furthermore, the scope of the data set has allowed us to consider the individual behaviour of firms of various sectors and sizes.

The evaluation proceeds in two stages. First, we have estimated the elasticities of the capital stock with respect to the user cost of capital and to the cash flow-capital ratio. The former may be related to the interest rate channel. The latter may be related to the credit channel since it may be interpreted as a measure of the degree of financial constraints, i.e. the difficulty to appeal to external financing. Second, we have computed the elasticities of both the user cost of capital and the cash flow-capital ratio with respect to the short-term market interest rate. Finally, we have calculated the combined effects of the two channels of monetary transmission on firms' capital stock and compared them across sectors and firms'size.

The analysis of firms' investment behaviour shows that: (1) large firms display a smoother investment pattern and are more responsive to value added growth than small firms, (2) small firms are more sensitive to the cash flow-capital ratio (except for manufacturing firms), which may indicate more binding financial constraints, (3) services firms do not respond to user cost fluctuations. Further, small services firms, contrary to large services 
firms, do not depend on value added growth but reply heavily on cash flow, (4) manufacturing firms react to user cost changes, value added fluctuations and cash flow. Small manufacturing firms are more responsive to the user cost of capital, and they do not seem to face more binding financial constraints than large manufacturing firms, (5) construction firms display higher elasticities with respect to the user cost than other sectors, (6) at a more disaggregated level, the elasticity of the capital stock with respect to value added and the user cost of capital is higher for capital-intensive sectors.

The evaluation of the effects of monetary policy on firms' investment yields the following results. The interest rate channel is stronger for small firms than for large firms. It produces larger effects in construction than in other sectors and it does not affect services firms significantly. Except for construction, the interest rate channel is larger for capitalintensive sectors than for other sectors. The credit channel is also stronger for small firms than for large firms, produces greater effects in the manufacturing sector than in other sectors, and exerts no significant influence on services firms. The order of magnitude of the credit channel is larger than that of the interest rate channel.

All in all, our results show that monetary policy has distributive effects on firms' investment, both through the interest rate channel and the credit channel. Following a monetary policy tightening, small firms cut their capital stock more than large firms, manufacturing firms reduce their capital stock by a larger extent than other sectors, and services remain essentially unaffected. The elasticity of capital with respect to interest rate changes ranges from zero to eighteen percent. 


\section{Introduction}

For the conduct of monetary policy it is essential to understand the transmission mechanism through which changes in the policy-controlled interest rate will affect the real economy and inflation. This mechanism is, however, rather complex since it operates through various channels and involves the behaviour of all sectors of the economy. In this paper we focus on how business investment is affected by monetary policy. This paper is part of the Monetary Transmission Network project conducted by EU-12 central banks and coordinated by the European Central Bank.

The literature usually distinguishes two channels through which business investment is influenced by monetary policy: an interest rate channel and a credit channel. The former channel conveys the direct impact of interest rate changes on the user cost of capital and subsequently on firms' investment. The latter channel only operates in a world of imperfect capital markets. Asymmetric information, moral hazard and agency costs between lenders and the firm drive a wedge between the internal (cash flow, liquidity) and external (debt, equity) cost of financing. Hence, firms' investment decisions are also determined by their financing decisions and opportunities. Not all firms face the same market interest rate; the level of the risk premium required by the lender depends on, among other things, the capital structure of the firm as recorded in the balance sheet ${ }^{1}$ (several papers develop these ideas, starting with Jensen and Meckling, 1976, Stiglitz and Weiss, 1981, Myers and Majluf, 1984). Some firms may even become credit-constrained and dependent for investment on internal resources. In such a world, monetary policy shocks will change the risk premium required by lenders if the shocks alter the net value of a firm and thus its ability to provide collateral. In addition, monetary policy shocks can affect the level of internal resources available by, for instance changing the amount of available cash flow.

In this paper we investigate the importance of both channels using a large panel of Belgian firms. Several reasons can be put forward for the use of micro-data rather than of aggregate data. First, micro-data contain a larger body of information. Second, they are closer to economic theory. Third, disaggregated data record firms in different financial positions. Fourth, panel data also allow us to control for both time-varying and firmspecific effects, which aggregate time series or cross-sectional data cannot do.

1 The (broad) credit channel is therefore also called the balance sheet channel. 
Following Bond et al. (1997) or Mairesse et al. (1999), we estimate a reduced-form investment equation, which is derived from the traditional neo-classical model of investment (Jorgenson, 1963). In this model, investment is solely a function of sales and a user cost. In contrast to Bond et al. (1997) we use a firm-specific user cost of capital. Adjustment costs, installation lags and expectations regarding future returns, which are inherent in the investment decision, are captured by the introduction of lagged variables. As in the extensive empirical literature pioneered by Fazzari et al. (1988), we also augment this neo-classical model by the cash flow/capital ratio. The coefficient for cash flow may be interpreted as an indication of the degree of financial constraints, since investment of credit-constrained firms is more sensitive to the availability of internal funds, i.e. cash flow. This interpretation should, however, be treated with caution, as Kaplan and Zingales (1997) have shown that it may be misleading, because cash flow may be correlated with firm profitability, and since current profits can be interpreted as a proxy for profit expectations. In this case, cash flow captures profit expectations rather than credit constraints.

In light of the Lucas critique (1976), another strand of empirical research on investment adopts a more structural approach and tries to derive a tightly parameterised model from the firm's intertemporal optimisation problem under explicit assumptions (e.g. an explicit adjustment cost function, often quadratic, or the introduction of binding credit constraints). This type of work directly estimates the Euler equation for the capital stock (see, for instance, Bond and Meghir, 1994, Chatelain and Teurlai, 2000, Whited, 1992). Although from a theoretical point of view this approach is more appropriate (since it delivers policy-invariant parameter estimates), it has often failed to produce significant and correctly signed adjustment cost parameters (see for instance, Barran and Peeters, 1998, for Belgium). Chatelain and Teurlai (2000) argue that the assumption of a symmetric quadratic adjustment cost function may be too restrictive. Moreover, although the Euler equation itself is structural, the variables that explain the financial constraints are entered ad hoc after the firm's optimisation is solved (see the criticism of Vermeulen, 1998).

In contrast to previous panel data studies, including those on the Belgian economy (see Barran and Peeters, 1998, Deloof, 1998, Vermeulen, 1998), which generally focus on a very limited sample of large and/or manufacturing firms, we include in our study firms of all sectors and sizes. Moreover, our data set is comprehensive in the sense that it includes nearly every Belgian firm. Thanks to the size and scope of our data set we can analyse the investment behaviour of a typical Belgian firm without being subject to a representation 
bias. Moreover, we can allow for heterogeneity in firms' investment behaviour along multiple dimensions, whereas most studies force all firms into a "one size fits all" investment model by pooling the $\mathrm{data}^{2}$. In this paper we estimate a specific investment equation for each sector and size separately, and, by doing so, avoid a specification bias. Indeed, using pooled data does not produce significant effects of user-cost fluctuations on the investment rate, and formal tests show that this results from a specification bias. This highlights the need for a disaggregated analysis. Furthermore, such an analysis gives us additional information on the distributional effects of monetary policy.

The paper is organised as follows. Section 2 derives the reduced-form investment equation from the neo-classical model. Section 3 describes our dataset and some features of corporate finance in Belgium. The empirical part is split into two. Section 4 presents the estimates of the investment equation by sector and size. Section 5 computes the impact of interest rate changes on capital through the firm-specific user cost of capital and through the cash flow/capital ratio. Finally, in section 6, we formulate our conclusions.

\section{Theoretical framework}

In order to evaluate the interest rate and credit channels we proceed in two steps. In the first step we estimate an investment equation (4) derived from a neo-classical model. In the second step we focus on the impact of monetary policy on the user cost of capital and on the cash flow/capital ratio.

It can be shown, as in Mairesse et al. (1999), that the neo-classical model of a profitmaximising firm (as pioneered by Jorgenson, 1963) leads to the following capital demand equation, when we assume a generalised CES production function (as in Eisner and Nadiri, 1968), no irreversibility, uncertainty, delivery lags, costs of adaptation and taxes:

$$
\log \left(\mathrm{K}_{\mathrm{it}}\right)=\theta \cdot \log \left(\mathrm{Y}_{\mathrm{it}}\right)-\sigma \cdot \log \left(\mathrm{UCC}_{\mathrm{it}}\right)+\log \left(\mathrm{H}_{\mathrm{it}}\right)
$$

where $\mathrm{UCC}_{\mathrm{it}}$ is the real user cost of capital of firm $\mathrm{i}$ in year $\mathrm{t}$,

$\mathrm{Y}_{\mathrm{it}}$ represents real output,

$\mathrm{H}_{\mathrm{it}}=\left[\mathrm{TFP}_{\mathrm{i}} \cdot \mathrm{A}_{\mathrm{t}}\right]^{(\sigma-1) / v}\left(v \alpha_{\mathrm{i}}\right)^{\sigma}$, where $\mathrm{TFP}_{\mathrm{i}} \cdot \mathrm{A}_{\mathrm{t}}$ stands for total factor productivity, $v$ is the elasticity of scale,

2 Applying recent work by Pesaran, Shin and Smith (1999) constitutes an improvement in this respect since they only impose long-run homogeneity and allow the short-run dynamics to vary across groups. 
$\sigma$ is the elasticity of substitution between capital and labour,

$\alpha_{\mathrm{i}}$ is the capital share,

$$
\theta=\left(\sigma+\frac{1-\sigma}{v}\right) \text {. }
$$

Equation (1) represents the equilibrium value of the real capital stock. As can be shown from the expression for $\theta$, the long-run elasticity of capital to output is unity when $\sigma=1$ (Cobb-Douglas) or when $v=1$ (constant returns to scale).

Assuming a partial adjustment process of order $\mathrm{p}$, we obtain the following autoregressive distributed lag (ADL) capital demand equation ${ }^{3}$ :

$$
\begin{aligned}
\log \left(\mathrm{K}_{\mathrm{it}}\right) & =\varpi_{1} \cdot \log \left(\mathrm{K}_{\mathrm{it}-1}\right)+\varpi_{2} \cdot \log \left(\mathrm{K}_{\mathrm{it}-2}\right)+\ldots+\varpi_{\mathrm{p} \cdot} \log \left(\mathrm{K}_{\mathrm{it}-\mathrm{p}}\right) \\
& -\sigma_{0} \cdot \log \left(\mathrm{UCC}_{\mathrm{it}}\right)-\sigma_{1} \cdot \log \left(\mathrm{UCC}_{\mathrm{it}-1}\right)-\sigma_{2} \cdot \log \left(\mathrm{UCC}_{\mathrm{it}-2}\right)-\ldots . \sigma_{\mathrm{p} \cdot} \cdot \log \left(\mathrm{UCC}_{\mathrm{it}-\mathrm{p}}\right) \\
& +\theta_{0} \cdot \log \left(\mathrm{Y}_{\mathrm{it}}\right)+\theta_{1} \cdot \log \left(\mathrm{Y}_{\mathrm{it}-1}\right)+\theta_{2} \cdot \log \left(\mathrm{Y}_{\mathrm{it}-2}\right)+\ldots .+\theta_{\mathrm{p}} \cdot \log \left(\mathrm{Y}_{\mathrm{it}-\mathrm{p}}\right) \\
& +\phi_{0} \cdot \log \left(\mathrm{H}_{\mathrm{it}}\right)+\phi_{1} \cdot \log \left(\mathrm{H}_{\mathrm{it}-1}\right)+\phi_{2} \cdot \log \left(\mathrm{H}_{\mathrm{it}-2}\right)+\ldots .+\phi_{\mathrm{p}} \cdot \log \left(\mathrm{H}_{\mathrm{it}-\mathrm{p}}\right)
\end{aligned}
$$

Next, as in the usual accelerator model, we take first differences and approximate the net growth in the capital stock $\Delta \log \left(\mathrm{K}_{\mathrm{it}}\right)$ by $\mathrm{I}_{\mathrm{it}} / \mathrm{K}_{\mathrm{it}-1}-\delta_{\mathrm{i}}$ where $\delta_{\mathrm{i}}$ is the firm-specific depreciation rate. This leaves us with the equation :

$$
\begin{aligned}
& \left(\mathrm{I}_{\mathrm{it}} / \mathrm{K}_{\mathrm{it}-1}\right)=\left(1-\varpi_{1}-\varpi_{2}-\ldots \varpi_{\mathrm{p}}\right) \cdot \delta_{\mathrm{i}}+\varpi_{1} \cdot\left(\mathrm{I}_{\mathrm{it}-1} / \mathrm{K}_{\mathrm{it}-2}\right)+\varpi_{2} \cdot\left(\mathrm{I}_{\mathrm{it}-2} / \mathrm{K}_{\mathrm{it}-3}\right)+\ldots+\varpi_{\mathrm{p} \cdot}\left(\mathrm{I}_{\mathrm{it}-\mathrm{p}} / \mathrm{K}_{\mathrm{it}-\mathrm{p}-1}\right) \\
& -\sigma_{0} \cdot \Delta \log \left(\mathrm{UCC}_{\mathrm{it}}\right)-\sigma_{1} \cdot \Delta \log \left(\mathrm{UCC}_{\mathrm{it}-1}\right)-\sigma_{2} \cdot \Delta \log \left(\mathrm{UCC}_{\mathrm{it}-2}\right)-\ldots .-\sigma_{\mathrm{p}} \cdot \Delta \log \left(\mathrm{UCC}_{\mathrm{it}-\mathrm{p}}\right) \\
& +\theta_{0} \cdot \Delta \log \left(\mathrm{Y}_{\mathrm{it}}\right)+\theta_{1} \cdot \Delta \log \left(\mathrm{Y}_{\mathrm{it}-1}\right)+\theta_{2} \cdot \Delta \log \left(\mathrm{Y}_{\mathrm{it}-2}\right)+\ldots .+\theta_{\mathrm{p}} \cdot \Delta \log \left(\mathrm{Y}_{\mathrm{it}-\mathrm{p}}\right) \\
& + \text { time dummies }+\varepsilon_{\text {it }}
\end{aligned}
$$

Finally, this equation is augmented with a distributed lag of the cash flow/capital ratio, denoted by $\mathrm{Cash}_{\mathrm{it}}$, in order to capture financing constraints.

Equation (3) deviates from Mairesse et al. (1999) because we do not replace the user cost by time dummies and fixed effects. Furthermore, in most studies output is proxied by sales. However, since small firms do not have to report sales in Belgium, we use instead value added $\left(\mathrm{VA}_{\mathrm{it}}\right)$ for all firms. If we make the assumption that value added is

3 Rearranging this equation, as in Mairesse et al. (1999), we obtain an error correction model which expresses the growth rate of the capital stock as a function of both growth rate and level variables. Theoretically, this equation has more appeal, because it distinguishes between long- and short-term effects. However, empirically capturing the long-term over a limited period of time is a perilous undertaking. 
proportional to sales, the coefficient for output in equation (1) keeps the same structural interpretation for value added. So, we finally obtain the following estimable equation:

$$
\begin{aligned}
\left(\mathrm{I}_{\mathrm{it}} / \mathrm{K}_{\mathrm{it}-1}\right)=\left(1-\varpi_{1}-\varpi_{2}-\ldots \varpi_{\mathrm{p}}\right) \cdot \delta_{\mathrm{i}}+\varpi_{1} \cdot\left(\mathrm{I}_{\mathrm{it}-1} / \mathrm{K}_{\mathrm{it}-2}\right)+\varpi_{2} \cdot\left(\mathrm{I}_{\mathrm{it}-2} / \mathrm{K}_{\mathrm{it}-3}\right)+\ldots+\varpi_{\mathrm{p} \cdot} \cdot\left(\mathrm{I}_{\mathrm{it}-\mathrm{p}} / \mathrm{K}_{\mathrm{it}-\mathrm{p}-1}\right) \\
\quad-\sigma_{0} \cdot \Delta \log \left(\mathrm{UCC}_{\mathrm{it}}\right)-\sigma_{1} \cdot \Delta \log \left(\mathrm{UCC}_{\mathrm{it}-1}\right)-\sigma_{2} \cdot \Delta \log \left(\mathrm{UCC}_{\mathrm{it}-2}\right)-\ldots . \sigma_{\mathrm{p}} \cdot \Delta \log \left(\mathrm{UCC}_{\mathrm{it}-\mathrm{p}}\right) \\
\quad+\theta_{0} \cdot \Delta \log \left(\mathrm{VA}_{\mathrm{it}}\right)+\theta_{1} \cdot \Delta \log \left(\mathrm{VA}_{\mathrm{it}-1}\right)+\theta_{2} \cdot \Delta \log \left(\mathrm{VA}_{\mathrm{it}-2}\right)+\ldots+\theta_{\mathrm{p}} \cdot \Delta \log \left(\mathrm{VA}_{\mathrm{it}-\mathrm{p}}\right) \\
\quad+\beta_{0} \cdot \operatorname{Cash}_{\mathrm{it}}+\beta_{1} \cdot \mathrm{Cash}_{\mathrm{it}-1}+\beta_{2} \cdot \mathrm{Cash}_{\mathrm{it}-2}+\ldots .+\beta_{\mathrm{p}} \cdot \mathrm{Cash}_{\mathrm{it}-\mathrm{p}} \\
\quad+\text { time dummies }+\varepsilon_{\mathrm{it}}
\end{aligned}
$$

Time dummies are sufficient to capture the terms in $\Delta \log \left(\mathrm{H}_{\mathrm{it}}\right)$ (since the firm-specific effects, $\mathrm{TFP}_{\mathrm{i}}$ and $\alpha_{\mathrm{i}}$, drop out by first differencing), but we still need a fixed effect to deal with the firm-specific depreciation rate ${ }^{4}$. The presence of the lagged dependent variable and the likely endogeneity of output, user cost and cash flow require an instrumental variable approach in order to obtain consistent estimates. We use the Arellano and Bond (1991) GMM estimator on first differences. We consider the largest set of instruments available, i.e. second lag and beyond of the investment-capital ratio, of the first differenced user cost, the first differenced value added and cash flow/capital ratio. For the sake of brevity, in section 4, we present only the results of the second-step estimates, which are robust to residual heteroskedasticity. Since equation (4) is estimated in first differences in order to eliminate the fixed effects and since we consider four lags, we need at least seven years of observations per firm ${ }^{5}$. The estimation therefore runs over the period 1991-1998, and the earliest instrument is dated 1986.

\section{Description of Belgian data}

\subsection{Sample description 6}

Equation (4) above is estimated using a sample of firms drawn from a database collected by the National Bank of Belgium. The database covers nearly the entire population of Belgian firms, since, under accounting legislation, almost every non-financial firm ${ }^{7}$ in

4 Even assuming a non-specific depreciation rate might still require a fixed effect, when productivity growth instead of the level is firm-specific.

5 Wald tests, reported in the tables, show that, in most of the cases, lag four is significant. Further, preliminary estimates show that an ADL(3) model is misspecified for small firms (in the sense that the Sargan statistic rejects the model).

6 A more detailed description of the data is to be found in Appendix A.

7 In general, except for financial intermediaries, which have to obey special rules, only natural persons are exempted from publication of their annual accounts and all other firms governed by Belgian law are not. More specifically, the latter group includes : 
Belgium has to deposit an annual account at the National Bank of Belgium. In 1998, for instance, 228,566 firms met their legal obligation. On average about 10\% of the Belgian firms, however, fail to comply with this requirement, so that no information is available for those firms. All accounts are subjected to a long list of accounting and logical consistency controls before they enter the database. If necessary, corrections are made. The data therefore satisfy the highest quality standards.

The annual accounts of small firms, which represent the vast majority in the database (around $92.5 \%$ of all firms), are submitted in a different format from that of large firms and essentially contain less information. A company is regarded as "large", in 1999, either when the yearly average of its workforce is at least 100 or when at least two of the following thresholds were exceeded: (1) yearly average of workforce: 50, (2) turnover (excluding VAT) : EUR 6,250,000, (3) balance sheet total : EUR 3,125,000². In general, the values of the latter two thresholds are altered every four years in order to take account of inflation. In terms of aggregate economic activity, large firms, of course, account for a large proportion of the private sector.

Our sample draws on a period of 15 years (1985-1998) $)^{9}$ of annual accounts. This makes the database suitable for studying the dynamic properties of the model. We also use an unbalanced panel in order to avoid the survivor bias, related to balancedness, and to keep as much information as possible, which should lead to more efficient estimates. We selected firms for inclusion in our sample when all variables in equation (4) were available for at least 7 years. Although we are well aware that this might introduce another survivor bias, we give priority to the issue of dynamics. We furthermore removed outliers by excluding firm-years for which at least one of the variables of interest (except value added, which is scale-dependent) belongs to the first or $99^{\text {th }}$ percentile. This trimming procedure was repeated year by year and for large and small firms separately. We are left with a final unbalanced sample of 29,600 firms representing 157,547 observations. This is

- all limited liability companies;

- all economic joint ventures and European economic joint ventures;

- all unlimited liability companies if they are regarded as large and if at least one of their partners is a legal person ;

- all foreign companies which have a branch or a place of business in Belgium or wish to establish one there (legal obligation until 1991).

8 The definition of a large firm is close to the EU definition of a medium-sized or large firm. At the EU level, a firm is regarded as medium-sized if it has more than 50 employees and either a turnover higher than 7 million euros or a balance sheet total larger than 5 million euros.

9 Actually, the data set even contains 25 years of annual accounts, starting in the mid-1970s. However, due to changes in the accounting legislation, annual accounts before 1985 are difficult to compare to those from that year onwards. Hence, for our analysis, we prefer to work with a more consistent data set and to confine ourselves to the years 1985 to 1998. 
around $12 \%$ of the database, which originally amounted to more than one and a half million observations. Although this seems a small number, most of the observations lost are from very small (service) firms. The manufacturing firms in our retained sample produce around $46 \%$ of Belgian aggregate value added in manufacturing. For the service firms this is $16 \%$ of aggregate value added in services. Although there is a small bias towards large firms in our final sample, the number of very small firms is still quite large. Around $10 \%$ of the firms have only one employee, and $44 \%$ of the firms employ at most five persons. At the sectoral level, manufacturing industries and construction are slightly overrepresented in our final sample.

All in all, compared to other data sets used in the literature, our sample is still very representative of the Belgian private sector, since there is no major representation bias towards a particular industry (often manufacturing), size (often large firms), or some other feature depending on the purpose for which the data are collected.

\subsection{The financial structure of Belgian firms}

During the past 15 years, the relative share of the different sources of corporate financing has changed considerably, and this trend has been different for small and large firms. Tables 1 and 2 show, respectively, the share of the main balance sheet items for the two categories of firms. The stylised facts are the following. In general, firms rely less on trade debt than in the past. This tendency, which, of course, is also reflected in a decline in the items 'trade credit' and 'inventories', points to a more efficient use of funds. Furthermore, as far as large firms are concerned, we observe that equity has become more important, reaching more than $40 \%$ at the end of 1998, that the share of long-term bank credit has been almost halved and that non-bank loans have exploded. The share of the other liability items remains more or less unchanged. Also debt securities (corporate bonds or commercial paper) continue to play a minor role in the corporate financing decisions of large Belgian companies. Small firms, on the other hand, have kept roughly the same leverage as 15 years ago, but have shifted primarily from trade debt towards long-term bank financing. These patterns can be explained by referring to (changes in) the institutional features of Belgian financial markets.

In Belgium, firms' direct access to capital markets has historically always been limited. Few companies are listed on the stock exchange. In November 1995 the stock market capitalisation of Belgian firms represented $44 \%$ of GDP, as compared with $93 \%$ in the US and $130 \%$ in the United Kingdom (see Verschueren and Deloof, 1999). Furthermore, 
corporate bonds and loan markets hardly exist; commercial paper was issued for the first time in 1991. Instead, Belgian corporate finance is characterised by the presence of large shareholders, which often assume the structure of holding companies. They control many firms through pyramidal and complex ownership structures. Holding companies play a significant role not only in the financing but also in the management of their affiliated firms. Holding companies may substitute for poorly developed corporate capital markets.

Since the presence of holding companies has a long history, this feature cannot explain the recent trends observed in the financial structure of (large) firms. Firms may, however, also belong to another form of group, i.e. a multinational company. In Belgium, since 1982, multinational firms have been able to found a so-called 'co-ordination centre'. This is the main distinctive feature of the Belgian system. Co-ordination centres are allowed to provide support services and financial services to their affiliated firms on a low-tax basis $^{10}$. In their role of banker of the group, they have become the main source of external finance for their members. Fiscal incentives encourage firms linked to a co-ordination centre to transfer their retained earnings in the form of rights issues to their co-ordination centre. The centre will transfer these funds back to these firms in the form of debt. This mechanism explains the trends observed in the aggregate balance sheet of large firms : the boost in equity financing, which stems from co-ordination centres, as well as the growing importance of financial assets and other loans, which is attributable to affiliated firms. Bank credit, being more expensive, has become less attractive.

In sum, co-ordination centres, but also holding companies, can alleviate the financial constraints for affiliated firms through the provision of external funds at lower costs thanks to lower agency costs (less asymmetric information) and thanks to fiscal advantages. Access to an internal capital market has affected corporate finance. It explains why large firms have replaced bank credit by intra-group loans. Given the legal restrictions involved, this did not happen for small firms ${ }^{11}$.

10 Co-ordination centres belong to the services sector; their members may belong to other sectors.

11 Only multinational groups with a consolidated capital in excess of BEF 1 billion and an annual turnover of at least BEF 10 billion were allowed to set up a co-ordination centre. 
Table 1 : Financial structure of small firms

\begin{tabular}{|c|c|c|c|c|c|c|c|c|c|c|c|c|c|}
\hline & 86 & 87 & 88 & 89 & 90 & 91 & 92 & 93 & 94 & 95 & 96 & 97 & 98 \\
\hline $\begin{array}{l}\text { number of firms } \\
(000)\end{array}$ & 75.2 & 87.0 & 96.1 & 105.6 & 117.2 & 129.5 & 141.0 & 151.2 & 158.0 & 166.8 & 170.1 & 181.8 & $\overline{191.9}$ \\
\hline $\begin{array}{l}\text { total assets } \\
\text { (billions euro) }\end{array}$ & 25.2 & 29.4 & 34.5 & 40.9 & 45.9 & 50.9 & 56.9 & 62.2 & 67.5 & 72.5 & 77.7 & 85.3 & 92.8 \\
\hline \multicolumn{14}{|c|}{ Assets as \% of total } \\
\hline real fixed assets & 32.1 & 33.4 & 35.0 & 35.5 & 38.0 & 38.9 & 40.1 & 41.0 & 41.1 & 41.7 & 41.0 & 40.2 & 39.7 \\
\hline financial assets & 2.9 & 3.3 & 4.1 & 5.5 & 5.5 & 5.7 & 6.3 & 6.8 & 7.3 & 7.3 & 7.9 & 8.9 & 9.8 \\
\hline inventories & 20.3 & 19.6 & 18.0 & 16.6 & 16.1 & 15.6 & 15.0 & 14.3 & 14.1 & 13.7 & 13.0 & 12.4 & 12.2 \\
\hline $\begin{array}{l}\text { trade credit - } \\
\text { total }\end{array}$ & 23.7 & 22.5 & 21.7 & 20.7 & 19.5 & 18.9 & 17.6 & 17.1 & 17.1 & 17.1 & 17.5 & 17.7 & 16.9 \\
\hline other assets & 21.0 & 21.3 & 21.2 & 21.7 & 21.0 & 20.9 & 21.0 & 20.8 & 20.5 & 20.2 & 20.6 & 20.8 & 21.3 \\
\hline \multicolumn{14}{|c|}{ Liabilities as \% of total } \\
\hline $\begin{array}{l}\text { loans of credit } \\
\text { institutions }\end{array}$ & 16.9 & 17.9 & 19.0 & 21.1 & 22.2 & 22.3 & 23.6 & 23.7 & 24.0 & 24.4 & 25.1 & 24.6 & 24.1 \\
\hline maturity < 1 year & 5.6 & 5.4 & 5.4 & 6.4 & 6.0 & 6.0 & 6.2 & 5.6 & 5.4 & 5.6 & 5.8 & 5.6 & 5.5 \\
\hline maturity > 1 year & 11.3 & 12.5 & 13.6 & 14.7 & 16.2 & 16.4 & 17.5 & 18.1 & 18.6 & 18.8 & 19.4 & 19.0 & 18.6 \\
\hline $\begin{array}{l}\text { other financial } \\
\text { debt } \\
\text { - debt securities } \\
\text { - other loans }\end{array}$ & 2.8 & 2.9 & 3.0 & 3.2 & 3.3 & 3.7 & 4.2 & 4.3 & 4.5 & 4.6 & 4.7 & 4.8 & 4.9 \\
\hline trade debt & 24.0 & 22.9 & 22.4 & 21.2 & 19.9 & 19.1 & 17.6 & 16.9 & 16.9 & 16.8 & 15.9 & 15.7 & 15.2 \\
\hline other debt & 19.8 & 19.2 & 18.8 & 18.7 & 18.9 & 19.6 & 19.9 & 19.9 & 19.8 & 19.8 & 19.6 & 20.2 & 20.6 \\
\hline $\begin{array}{l}\text { equity } \quad \text { and } \\
\text { reserves }\end{array}$ & 34.4 & 35.3 & 35.0 & 34.1 & 33.9 & 33.5 & 32.9 & 33.3 & 33.0 & 32.6 & 32.9 & 32.7 & 33.2 \\
\hline other liabilities & 2.0 & 1.8 & 1.7 & 1.7 & 1.7 & 1.7 & 1.8 & 1.8 & 1.8 & 1.8 & 1.8 & 1.9 & 2.0 \\
\hline \multicolumn{14}{|c|}{ Flows as \% of assets } \\
\hline interest charges & 2.9 & 2.9 & 2.7 & 3.0 & 3.3 & 3.7 & 3.7 & 3.7 & 3.5 & 3.5 & 3.2 & 3.0 & 2.9 \\
\hline $\begin{array}{l}\text { net operating } \\
\text { profit }\end{array}$ & 6.3 & 6.3 & 6.3 & 5.6 & 5.0 & 4.8 & 4.4 & 3.9 & 4.1 & 4.2 & 4.2 & 4.3 & 4.6 \\
\hline gross investment & 11.1 & 11.9 & 13.4 & 13.7 & 13.6 & 12.5 & 11.9 & 10.5 & 9.7 & 9.0 & 8.6 & 8.4 & 8.5 \\
\hline cash flow & 9.8 & 10.1 & 10.5 & 9.8 & 9.0 & 8.4 & 8.2 & 7.4 & 7.4 & 7.4 & 7.3 & 7.6 & 8.4 \\
\hline
\end{tabular}


Table 2 : Financial structure of large firms

\begin{tabular}{|c|c|c|c|c|c|c|c|c|c|c|c|c|c|}
\hline & 86 & 87 & $\overline{88}$ & 89 & $\overline{90}$ & 91 & 92 & 93 & $\overline{94}$ & 95 & 96 & 97 & 98 \\
\hline $\begin{array}{l}\text { number of firms } \\
(000)\end{array}$ & 10.0 & 10.3 & 10.7 & 11.5 & 12.5 & 13.1 & 13.4 & 13.7 & 13.8 & 13.8 & 13.5 & 13.6 & 13.8 \\
\hline $\begin{array}{l}\text { total assets } \\
\text { (billions euro) }\end{array}$ & 135.4 & 157.5 & 186.6 & 226.4 & 254.7 & 281.3 & 297.7 & 309.7 & 325.3 & 342.0 & 355.3 & 396.5 & 447.6 \\
\hline \multicolumn{14}{|c|}{ Assets as \% of total } \\
\hline real fixed assets & 25.1 & 23.1 & 20.9 & 19.7 & 19.7 & 19.5 & 19.2 & 18.5 & 17.6 & 16.6 & 16.5 & 15.2 & 14.0 \\
\hline financial assets & 13.5 & 20.2 & 22.3 & 23.2 & 25.2 & 25.7 & 25.9 & 27.3 & 28.4 & 28.7 & 30.2 & 29.3 & 31.9 \\
\hline inventories & 17.9 & 14.9 & 13.4 & 12.1 & 11.4 & 10.8 & 10.3 & 9.7 & 9.5 & 9.3 & 9.3 & 9.1 & 8.3 \\
\hline $\begin{array}{l}\text { trade credit - } \\
\text { total }\end{array}$ & 24.9 & 21.6 & 20.7 & 19.7 & 18.6 & 17.9 & 16.2 & 16.4 & 16.5 & 16.1 & 16.0 & 16.5 & 14.9 \\
\hline other assets & 18.5 & 20.2 & 22.6 & 25.3 & 25.2 & 26.1 & 28.3 & 28.0 & 28.0 & 29.3 & 28.0 & 29.8 & 30.9 \\
\hline \multicolumn{14}{|c|}{ Liabilities as \% of total } \\
\hline $\begin{array}{l}\text { loans of credit } \\
\text { institutions }\end{array}$ & 18.8 & 19.4 & 18.8 & 19.5 & 19.1 & 17.6 & 17.1 & 16.0 & 14.5 & 14.1 & 14.2 & 13.4 & 13.8 \\
\hline maturity < 1 year & 7.4 & 7.3 & 7.5 & 8.6 & 7.9 & 6.9 & 7.2 & 6.7 & 6.3 & 6.3 & 6.5 & 6.6 & 7.1 \\
\hline maturity > 1 year & 11.5 & 12.1 & 11.3 & 10.9 & 11.2 & 10.7 & 9.9 & 9.3 & 8.2 & 7.8 & 7.7 & 6.8 & 6.6 \\
\hline $\begin{array}{l}\text { other financial } \\
\text { debt }\end{array}$ & 7.3 & 7.6 & 8.4 & 9.9 & 11.0 & 12.6 & 13.9 & 12.8 & 13.5 & 14.0 & 13.7 & 14.5 & 15.0 \\
\hline - debt securities & 2.3 & 2.9 & 2.6 & 2.4 & 2.1 & 2.2 & 2.0 & 2.2 & 2.0 & 1.8 & 2.2 & 1.9 & 2.3 \\
\hline - other loans & 5.0 & 4.7 & 5.9 & 7.5 & 8.9 & 10.4 & 11.9 & 10.5 & 11.5 & 12.1 & 11.4 & 12.6 & 12.7 \\
\hline trade debt & 19.3 & 16.9 & 16.8 & 15.5 & 14.2 & 13.6 & 12.6 & 12.6 & 12.7 & 12.5 & 12.4 & 12.7 & 11.7 \\
\hline other debt & 18.8 & 17.2 & 17.1 & 16.4 & 15.6 & 15.8 & 15.9 & 16.3 & 15.6 & 15.2 & 14.9 & 14.7 & 13.9 \\
\hline $\begin{array}{ll}\text { equity } & \text { and } \\
\text { reserves } & \end{array}$ & 30.7 & 34.1 & 34.3 & 34.7 & 36.0 & 36.4 & 36.5 & 38.0 & 39.6 & 40.0 & 40.5 & 40.3 & 41.7 \\
\hline other liabilities & 5.1 & 4.8 & 4.6 & 4.1 & 4.0 & 4.0 & 4.0 & 4.3 & 4.1 & 4.2 & 4.4 & 4.3 & 4.0 \\
\hline \multicolumn{14}{|c|}{ Flows as $\%$ of assets } \\
\hline interest charges & 2.6 & 2.4 & 2.2 & 2.5 & 3.0 & 3.1 & 3.3 & 3.0 & 2.5 & 2.4 & 2.0 & 1.8 & 1.8 \\
\hline $\begin{array}{ll}\text { net } & \text { operating } \\
\text { profit } & \end{array}$ & 5.2 & 4.2 & 4.4 & 4.0 & 3.1 & 2.6 & 2.3 & 1.9 & 2.5 & 2.6 & 2.5 & 2.7 & 2.5 \\
\hline gross investment & 5.8 & 5.8 & 5.8 & 5.9 & 5.8 & 4.9 & 4.3 & 3.5 & 3.1 & 3.3 & 3.5 & 3.3 & 3.3 \\
\hline cash flow & 9.4 & 9.6 & 9.8 & 10.5 & 8.4 & 7.8 & 7.1 & 7.3 & 7.1 & 7.6 & 7.2 & 8.4 & 9.2 \\
\hline
\end{tabular}

\section{Investment behaviour of Belgian firms}

We have shown in previous section that our sample has an extremely broad scope. It contains firms of all sizes and of all sectors of the economy. We exploit this feature by estimating equation (4) over the entire sample and for different subgroups. This allows us not only to describe the investment behaviour of a typical firm in our sample (which corresponds roughly to a typical Belgian firm) but also to investigate the investment behaviour of specific subgroups of firms. As will be seen below, results vary significantly across subgroups.

We proceed as follows. In section 4.1. we estimate the investment equation for a typical firm in our sample, and for large and small firms separately. Next, we analyse the investment behaviour of manufacturing firms, service firms and construction firms, each 
being divided into subgroups of large and small firms. In section 4.3. we look more deeply into why user cost elasticities might differ across industries.

\subsection{Investment of a typical firm and investment by size}

We first estimate the ADL(4) model of investment augmented with cash flow, presented in equation (4), for the complete sample. Results are presented in Table 3 (columns 2 and $3)$. The dynamics of the investment rate are driven by the coefficients on the lagged investment rate. The coefficient on the first lag of the investment rate is insignificant and its point estimate is close to zero. The coefficients of further lags are negative and significant, albeit rather small. This indicates that bursts of investment do not spill over to the next years, but are followed by lower investment rates two years later. This result should not be too surprising. Results on plant level data by Doms and Dunne (1998) also point towards periodic bursts of investment. Moreover, consider again that $44 \%$ of the firms in our sample are very small, having at most five employees. They are thus likely to operate only one plant, with an overwhelming investment effort in the first year of activity. This pattern makes investment a less smooth process ${ }^{12}$.

In contrast with neo-classical theory, none of the user cost coefficients is significant. However, as will be seen below, this result disappears for certain subgroups. The growth of value added is significant at lags 1 and 2, although the effect remains small. A 1\% point increase in value added growth causes the investment rate to increase by $0.03 \%$ point after one year and another $0.026 \%$ after two years. The cash flow/capital ratio is significant at lags 0,1 and 3. The contemporaneous effect is the largest. A $1 \%$ point increase in the cash flow/capital ratio leads to a $0.11 \%$ point increase in the investment rate.

12 At branch level (see section 4.2.), we still find that, in general, the coefficient on the first lag of the investment rate is negative and larger in absolute value for small firms. 
Table 3: ADL(4) investment model for large and small firms

\begin{tabular}{|c|c|c|c|c|c|c|}
\hline & \multicolumn{2}{|c|}{ all firms } & \multicolumn{2}{|c|}{ large firms } & \multicolumn{2}{|c|}{ small firms } \\
\hline & coef & t-stat & coef & t-stat & coef & t-stat \\
\hline$\overline{\mathrm{I}_{\mathrm{t}-1} / \mathrm{K}_{\mathrm{t}-2}}$ & -0.001 & -0.128 & $0.074 * * *$ & 5.789 & 0.017 & 1.602 \\
\hline $\mathrm{I}_{\mathrm{t}-2} / \mathrm{K}_{\mathrm{t}-3}$ & $-0.027 * * *$ & -6.006 & $-0.017 * *$ & -2.131 & $-0.019 * * *$ & -3.455 \\
\hline $\mathrm{I}_{\mathrm{t}-3} / \mathrm{K}_{\mathrm{t}-4}$ & $-0.020 * * *$ & -5.118 & -0.006 & -0.817 & $-0.018 * * *$ & -3.910 \\
\hline $\mathrm{I}_{\mathrm{t}-4} / \mathrm{K}_{\mathrm{t}-5}$ & $-0.012 * * *$ & -3.283 & -0.005 & -0.759 & $-0.011 * * *$ & -2.779 \\
\hline$\Sigma\left(I_{t-j} / K_{t-j-1}\right)$ & $-0.060 * * *$ & -5.966 & $0.046 *$ & 1.878 & $-0.030 * * *$ & 3.000 \\
\hline$\Delta \log \left(\mathrm{UCC}_{\mathrm{t}}\right)$ & 0.010 & 0.934 & 0.010 & 0.973 & 0.006 & 0.437 \\
\hline$\Delta \log \left(\mathrm{UCC}_{\mathrm{t}-1}\right)$ & 0.007 & 1.362 & 0.003 & 0.484 & 0.006 & 0.965 \\
\hline$\Delta \log \left(\mathrm{UCC}_{\mathrm{t}-2}\right)$ & $0.008 *$ & 1.946 & 0.004 & 0.757 & 0.007 & 1.429 \\
\hline$\Delta \log \left(\mathrm{UCC}_{\mathrm{t}-3}\right)$ & 0.003 & 0.999 & 0.003 & 0.662 & 0.003 & 0.721 \\
\hline$\Delta \log \left(\mathrm{UCC}_{\mathrm{t}-4}\right)$ & 0.002 & 0.694 & -0.002 & -0.532 & 0.002 & 0.696 \\
\hline$\Sigma \Delta \log \left(U C C_{t-j}\right)$ & 0.030 & 1.556 & 0.018 & 1.039 & 0.024 & 1.200 \\
\hline Long-run elasticity & 0.028 & & 0.019 & & 0.023 & \\
\hline$\Delta \log \left(\mathrm{VA}_{\mathrm{t}}\right)$ & 0.006 & 0.149 & 0.074 & 1.509 & -0.023 & -0.519 \\
\hline$\Delta \log \left(\mathrm{VA}_{\mathrm{t}-1}\right)$ & $0.032 * *$ & 2.457 & $0.049 * * *$ & 3.049 & 0.011 & 0.727 \\
\hline$\Delta \log \left(\mathrm{VA}_{\mathrm{t}-2}\right)$ & $0.026 * * *$ & 3.096 & $0.033 * * *$ & 2.908 & 0.011 & 1.075 \\
\hline$\Delta \log \left(\mathrm{VA}_{\mathrm{t}-3}\right)$ & -0.001 & -0.128 & 0.009 & 0.857 & -0.010 & -1.099 \\
\hline$\Delta \log \left(\mathrm{VA}_{\mathrm{t}-4}\right)$ & 0.008 & 1.491 & 0.009 & 1.123 & 0.007 & 1.132 \\
\hline$\Sigma \Delta \log \left(V A_{t-i}\right)$ & 0.070 & 1.113 & $0.174 * *$ & 2.246 & -0.004 & -0.056 \\
\hline Long-run elasticity & 0.066 & & 0.182 & & -0.004 & \\
\hline $\mathrm{CASH}_{\mathrm{t}}$ & $0.109 * * *$ & 2.750 & $0.067 * * *$ & 3.230 & $0.416 * * *$ & 5.239 \\
\hline $\mathrm{CASH}_{\mathrm{t}-1}$ & $0.047 * * *$ & 3.046 & 0.015 & 1.456 & -0.017 & -0.606 \\
\hline $\mathrm{CASH}_{\mathrm{t}-2}$ & 0.004 & 0.638 & - 0.003 & -0.545 & -0.014 & -1.165 \\
\hline $\mathrm{CASH}_{\mathrm{t}-3}$ & $0.017 * * *$ & 2.581 & $0.023 * * *$ & 3.984 & -0.001 & -0.083 \\
\hline $\mathrm{CASH}_{\mathrm{t}-4}$ & -0.007 & -1.055 & -0.001 & -0.090 & $-0.020 *$ & -1.954 \\
\hline$\Sigma C A S H_{t-j}$ & $0.170 * * *$ & 6.259 & $0.101 * * *$ & 5.831 & $0.365 * * *$ & 8.161 \\
\hline \multirow[t]{2}{*}{ Long-run elasticity } & 0.160 & & 0.106 & & 0.354 & \\
\hline & statistic & p-value & statistic & p-value & statistic & p-value \\
\hline No. of obs. & 157547 & & 27174 & & 129265 & \\
\hline No. of firms & 29600 & & 4823 & & 25000 & \\
\hline Sargan & 145.66 & 0.100 & 131.31 & 0.332 & 135.87 & 0.239 \\
\hline Wald - lag 4 & 17.641 & 0.001 & 1.827 & 0.768 & 19.983 & 0.001 \\
\hline $\mathrm{m} 1$ & -44.51 & 0.000 & -22.07 & 0.000 & -41.73 & 0.000 \\
\hline \multirow[t]{2}{*}{$\mathrm{m} 2$} & -2.24 & 0.025 & -0.99 & 0.322 & -1.68 & 0.093 \\
\hline & coef & t-stat & coef & t-stat & coef & t-stat \\
\hline$\sum\left(\mathrm{I}_{\mathrm{t}-\mathrm{j}} / \mathrm{K}_{\mathrm{t}-\mathrm{j}-1}\right) \cdot \mathrm{D}_{\text {construction }}$ & $-0.107 * *$ & -2.333 & $-0.169 * *$ & -2.078 & -0.032 & -0.580 \\
\hline$\Sigma\left(\mathrm{I}_{\mathrm{t}-\mathrm{j}} / \mathrm{K}_{\mathrm{t}-\mathrm{j}-1}\right) \cdot \mathrm{D}_{\text {services }}$ & -0.008 & -0.192 & $-0.101 *$ & -1.850 & 0.076 & 1.595 \\
\hline$\Sigma \Delta \log \left(\mathrm{UCC}_{\mathrm{t}-\mathrm{j}}\right) \cdot \mathrm{D}_{\text {construction }}$ & 0.044 & 0.851 & $-0.127 * *$ & -2.088 & 0.022 & 0.323 \\
\hline$\Sigma \Delta \log \left(\mathrm{UCC}_{\mathrm{t}-\mathrm{j}}\right) \cdot \mathrm{D}_{\text {services }}$ & 0.029 & 0.665 & 0.013 & 0.297 & 0.011 & 0.149 \\
\hline$\Sigma \Delta \log \left(\mathrm{VA}_{\mathrm{t}-\mathrm{j}}\right) \cdot \mathrm{D}_{\text {construction }}$ & -0.028 & -0.189 & -0.224 & -1.521 & 0.063 & 0.410 \\
\hline$\Sigma \Delta \log \left(\mathrm{VA}_{\mathrm{t}-\mathrm{j}}\right) \cdot \mathrm{D}_{\text {services }}$ & $-0.311 * *$ & -2.417 & $-0.222 *$ & -1.687 & -0.143 & -1.054 \\
\hline$\Sigma \mathrm{CASH}_{\mathrm{t}-\mathrm{j}} \cdot \mathrm{D}_{\text {construction }}$ & $0.176 * *$ & 2.309 & 0.082 & 1.308 & 0.106 & 1.108 \\
\hline$\Sigma \mathrm{CASH}_{\mathrm{t}-\mathrm{j}} \cdot \mathrm{D}_{\text {services }}$ & 0.056 & 0.837 & -0.035 & -0.610 & 0.158 & 1.237 \\
\hline
\end{tabular}

2nd step GMM Arellano-Bond estimates of the investment equation (4) over 1991-1998 the constant and time dummies are not shown

$*$ significant at the $10 \%$ level; ** significant at the $5 \%$ level; *** significant at the $1 \%$ level 
Although the above results represent the typical behaviour of a firm in the sample, it is interesting to split the sample into subgroups and investigate the investment behaviour of those groups separately. A first logical split of the sample is by size. The vast majority of the firms in our sample is (very) small. This is a reflection of the fact that our sample is drawn from a database that covers the Belgian economy practically completely. As a consequence, large firms, although they are usually more important from a macroeconomic perspective, carry less weight in a pooled regression together with numerous small firms. Hence, their behaviour will be masked in such a regression.

In addition, it has also been argued that small and large firms might have quite different investment behaviour. First, a series of papers has shown that small firms are likely to be more credit-constrained than large firms (see, for instance, Guiso, 1997, for Italy, Mörttinen, 2000, for inventories in Finland, Vermeulen, 2000, for Germany, France, Italy and Spain, Wesche, 2000, for Austria). As is explained in the previous section, in Belgium a number of large firms can alleviate financing constraints through co-ordination centres. Although this is still under debate (see Kaplan and Zingales, 1997, for a critical note), some authors have argued that these differences in the degree of financial constraints imply different cash flow sensitivities. We expect cash flow coefficients to be smaller for large firms. Second, large firms probably have more plants than small firms. Aggregation over several plants should lead to a smoother investment pattern for large firms.

We split our sample into large and small firms and estimate equation (4) for them separately. The results, presented in Table 3 (columns 4, 5 and 6,7), confirm the above conjectures. Large firms show a cash flow sensitivity that is about 3.5 times smaller than that of small firms: the sum of the cash flow coefficients is 0.10 for large firms and 0.365 for small firms. Especially contemporaneous cash flow seems to be a crucial determinant for small firms' investment. For a small firm, a $1 \%$ point increase in the cash flow/capital ratio leads to a $0.4 \%$ point increase in the investment rate; for large firms this is only $0.07 \%$ point. The dynamics of small- and large-firm investment are also quite different. The positive and significant coefficient of the by-one-period-lagged investment rate for large firms, compared to the insignificant one for small firms provides evidence of smoother investment behaviour by large firms. This is confirmed by a positive overall effect for large firms compared to a negative one for small firms. Due to stronger financial constraints, small firms might invest once they have the opportunity and available financing, and then wait for some time for new investment opportunities and funding. We computed for each firm the standard deviation of its investment rate over six years. The 
median of this statistic over the sample of small firms is $45 \%$ higher $(0.20)$ than that of large firms (0.138). Finally, the role of value added growth seems to be substantial for large firms only. For small firms, none of the coefficients on value added growth is significant.

Overall, the results suggest that large-firm investment is smoother, depends on fundamentals (value added growth, i.e. the accelerator model) and is less dependent on cash flow. Small-firm investment depends heavily on cash flow. Although we believe that this (at least partially) reflects severe financing constraints (given that the small firms are "very small"), it could also partially reflect the fact that cash flow is a more important predictor of future profits for small firms than for large firms. Note that the user cost of capital is never significant.

\subsection{Investment across broad sectors and size classes}

In this section we investigate differences across both sectors and size classes. We split the large and small subgroups further into 3 broad sectors of the economy, leading to 6 subgroups. We consider the following broad sectors:

(1) manufacturing sector: this includes food, textiles, paper, wood, metal, machinery, transport equipment, other industries, refineries, chemicals, plastics, non-metal;

(2) construction sector;

(3) service sector: this includes financial services, real estate, leasing and other services to firms, education, other services, retail sales, hotels and restaurants, and transport and communication.

Before we estimate equation (4) for the various subgroups, we first perform some formal testing of parameter heterogeneity across sectors by introducing dummies for the construction and service sectors in the regression on the complete sample, as well as on the large and small sample separately. We consider four separate regressions ${ }^{13}$ in which we include dummy variables successively on investment, the user cost, value added, and cash flow, for construction and for services. The bottom section of Table 3 shows the total effects together with their t-statistic. There is evidence of marked differences across

13 In an ADL(4) model, problems arise when the same dummies applied to all lags of all variables are not significant. Since this procedure is not standard, we estimate, as a robustness check, an ADL(2) model with dummies on all coefficients (except the time dummies), for small and large firms separately. We were able to obtain estimates in this case. The results are consistent with the above findings: there are significant differences across sectors. 
sectors in the long-term effect of the user cost and value added (especially for large firms). Also the investment dynamics seems to differ across sectors. This constitutes the reason for estimating equation (4) for each of the subgroups separately.

Table 4: ADL(4) model of investment by sector for large firms

\begin{tabular}{|c|c|c|c|c|c|c|}
\hline & \multicolumn{2}{|c|}{ manufacturing } & \multicolumn{2}{|c|}{ construction } & \multicolumn{2}{|l|}{ services } \\
\hline & coef & t-stat & coef & t-stat & coef & t-stat \\
\hline $\mathrm{I}_{\mathrm{t}-1} / \mathrm{K}_{\mathrm{t}-2}$ & $0.039 * * *$ & 2.899 & $0.049 * * *$ & 3.235 & $0.066 * * *$ & 4.703 \\
\hline $\mathrm{I}_{\mathrm{t}-2} / \mathrm{K}_{\mathrm{t}-3}$ & $-0.035 * * *$ & -3.291 & -0.010 & -0.766 & $-0.027 * * *$ & -3.019 \\
\hline $\mathrm{I}_{\mathrm{t}-3} / \mathrm{K}_{\mathrm{t}-4}$ & 0.011 & 1.073 & $-0.026 * *$ & -2.240 & $-0.017 * *$ & -2.053 \\
\hline $\mathrm{I}_{\mathrm{t}-4} / \mathrm{K}_{\mathrm{t}-5}$ & -0.001 & -0.096 & -0.012 & -1.196 & -0.011 & -1.515 \\
\hline$\Sigma\left(I_{t-j} / K_{t-j-1}\right)$ & 0.015 & 0.455 & 0.000 & -0.011 & 0.010 & 0.338 \\
\hline$\Delta \log \left(\mathrm{UCC}_{\mathrm{t}}\right)$ & -0.011 & -1.377 & $-0.034 * *$ & -2.034 & 0.016 & 1.144 \\
\hline$\Delta \log \left(\mathrm{UCC}_{\mathrm{t}-1}\right)$ & -0.006 & -1.001 & $-0.027 * *$ & -2.566 & 0.001 & 0.192 \\
\hline$\Delta \log \left(\mathrm{UCC}_{\mathrm{t}-2}\right)$ & -0.008 & -1.216 & 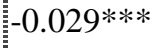 & -3.790 & 0.001 & 0.128 \\
\hline$\Delta \log \left(\mathrm{UCC}_{\mathrm{t}-3}\right)$ & -0.006 & -1.249 & -0.007 & -0.949 & 0.000 & 0.020 \\
\hline$\Delta \log \left(\mathrm{UCC}_{\mathrm{t}-4}\right)$ & -0.001 & -0.247 & 0.004 & 0.831 & -0.005 & -1.421 \\
\hline$\Sigma \Delta \log \left(U C C_{t-j}\right)$ & $-0.032 * * *$ & -3.181 & $-0.093 * * *$ & -2.800 & 0.013 & 0.567 \\
\hline Long-run elasticity & -0.032 & & -0.093 & & 0.013 & \\
\hline$\Delta \log \left(\mathrm{VA}_{\mathrm{t}}\right)$ & $0.143 * * *$ & 3.825 & 0.008 & 0.329 & $0.072 *$ & 1.755 \\
\hline$\Delta \log \left(\mathrm{VA}_{\mathrm{t}-1}\right)$ & $0.076 * * *$ & 4.601 & $0.053 * * *$ & 2.576 & $0.049 * * *$ & 3.109 \\
\hline$\Delta \log \left(\mathrm{VA}_{\mathrm{t}-2}\right)$ & $0.073 * * *$ & 5.116 & 0.023 & 1.281 & $0.035 * * *$ & 2.759 \\
\hline$\Delta \log \left(\mathrm{VA}_{\mathrm{t}-3}\right)$ & 0.016 & 1.355 & $-0.045 * * *$ & -2.988 & $0.021 *$ & 1.771 \\
\hline$\Delta \log \left(\mathrm{VA}_{\mathrm{t}-4}\right)$ & 0.000 & 0.021 & $-0.030 * *$ & -2.286 & 0.006 & 0.625 \\
\hline$\Sigma \Delta \log \left(V A_{t-j}\right)$ & $0.309 * * *$ & 4.403 & 0.008 & 0.118 & $0.183 * *$ & 2.543 \\
\hline Long-run elasticity & 0.313 & & 0.008 & & 0.185 & \\
\hline $\mathrm{CASH}_{\mathrm{t}}$ & $0.037 * *$ & 2.044 & $0.114 * * *$ & 3.724 & $0.054 * * *$ & 2.743 \\
\hline $\mathrm{CASH}_{\mathrm{t}-1}$ & $0.098 * * *$ & 6.357 & 0.007 & 0.599 & 0.009 & 0.872 \\
\hline $\mathrm{CASH}_{\mathrm{t}-2}$ & 0.011 & 0.914 & $0.016 * *$ & 2.307 & -0.005 & -0.880 \\
\hline $\mathrm{CASH}_{\mathrm{t}-3}$ & $0.040 * * *$ & 3.437 & -0.006 & -0.877 & $0.026 * * *$ & 4.245 \\
\hline $\mathrm{CASH}_{\mathrm{t}-4}$ & $0.021 * *$ & 2.093 & 0.003 & 0.415 & 0.000 & 0.018 \\
\hline$\Sigma C A S H_{t-i}$ & $0.207 * * *$ & 4.524 & $0.134 * * *$ & 6.676 & $0.083 * * *$ & 4.815 \\
\hline \multirow[t]{2}{*}{ Long-run elasticity } & 0.211 & & 0.133 & & 0.084 & \\
\hline & statistic & $\mathrm{p}$-value & statistic & $\mathrm{p}$-value & statistic & p-value \\
\hline No. of obs. & 8158 & & 2720 & & 16624 & \\
\hline No. of firms & 1529 & & 452 & & 2826 & \\
\hline Sargan & 119.501 & 0.622 & 118.816 & 0.639 & 118.957 & 0.635 \\
\hline Wald - lag 4 & 4.705 & 0.319 & 13.136 & 0.011 & 4.006 & 0.405 \\
\hline $\mathrm{m} 1$ & -11.716 & 0.000 & -8.011 & 0.000 & -17.400 & 0.000 \\
\hline $\mathrm{m} 2$ & 0.363 & 0.717 & -1.221 & 0.222 & -0.717 & 0.474 \\
\hline
\end{tabular}

2nd step GMM Arellano-Bond estimates of the investment equation (4) over 1991-1998 the constant and time dummies are not shown

$*$ significant at the $10 \%$ level; ** significant at the $5 \%$ level; *** significant at the $1 \%$ level 
Table 5: ADL(4) model of investment by sector for small firms

\begin{tabular}{|c|c|c|c|c|c|c|}
\hline & \multicolumn{2}{|c|}{ manufacturing } & \multicolumn{2}{|c|}{ construction } & \multicolumn{2}{|l|}{ services } \\
\hline & coef & t-stat & coef & t-stat & coef & t-stat \\
\hline$\overline{\mathrm{I}_{\mathrm{t}-1} / \mathrm{K}_{\mathrm{t}-2}}$ & $-0.029 *$ & -1.910 & $-0.034 * *$ & -2.320 & 0.018 & 1.456 \\
\hline $\mathrm{I}_{\mathrm{t}-2} / \mathrm{K}_{\mathrm{t}-3}$ & $-0.035 * * *$ & -3.210 & $-0.041 * * *$ & -4.177 & $-0.019 * * *$ & -3.148 \\
\hline $\mathrm{I}_{\mathrm{t}-3} / \mathrm{K}_{\mathrm{t}-4}$ & $-0.021 * *$ & -2.194 & $-0.047 * * *$ & -5.365 & $-0.015 * * *$ & -2.846 \\
\hline $\mathrm{I}_{\mathrm{t}-4} / \mathrm{K}_{\mathrm{t}-5}$ & $-0.028 * * *$ & -3.205 & $-0.036 * * *$ & -4.713 & -0.007 & -1.388 \\
\hline$\Sigma\left(I_{t-j} / K_{t-j-1}\right)$ & $-0.113 * * *$ & -2.736 & $-0.158 * * *$ & -4.755 & -0.023 & -1.157 \\
\hline$\Delta \log \left(\mathrm{UCC}_{\mathrm{t}}\right)$ & -0.032 & -1.643 & $-0.075^{* *}$ & -1.966 & 0.010 & 0.715 \\
\hline$\Delta \log \left(\mathrm{UCC}_{\mathrm{t}-1}\right)$ & $-0.023 *$ & -1.851 & -0.023 & -1.210 & 0.005 & 0.753 \\
\hline$\Delta \log \left(\mathrm{UCC}_{\mathrm{t}-2}\right)$ & $-0.021 *$ & -1.888 & 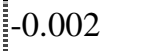 & -0.126 & 0.005 & 0.920 \\
\hline$\Delta \log \left(\mathrm{UCC}_{\mathrm{t}-3}\right)$ & $-0.016^{*}$ & -1.812 & -0.006 & -0.691 & 0.003 & 0.687 \\
\hline$\Delta \log \left(\mathrm{UCC}_{\mathrm{t}-4}\right)$ & -0.006 & -0.981 & 0.006 & 0.963 & -0.001 & -0.360 \\
\hline$\Sigma \Delta \log \left(U C C_{t-j}\right)$ & -0.097* & -1.949 & -0.099 & -1.293 & 0.022 & 0.985 \\
\hline Long-run elasticity & -0.088 & & -0.086 & & 0.022 & \\
\hline$\Delta \log \left(\mathrm{VA}_{\mathrm{t}}\right)$ & 0.095 & 1.623 & 0.029 & 0.504 & -0.017 & -0.364 \\
\hline$\Delta \log \left(\mathrm{VA}_{\mathrm{t}-1}\right)$ & $0.083 * * *$ & 3.481 & $0.067 * * *$ & 3.269 & 0.008 & 0.464 \\
\hline$\Delta \log \left(\mathrm{VA}_{\mathrm{t}-2}\right)$ & $0.041 *$ & 1.919 & $0.054 * * *$ & 3.339 & 0.006 & 0.549 \\
\hline$\Delta \log \left(\mathrm{VA}_{\mathrm{t}-3}\right)$ & $0.038 * *$ & 1.962 & $0.034 * *$ & 2.452 & -0.014 & -1.355 \\
\hline$\Delta \log \left(\mathrm{VA}_{\mathrm{t}-4}\right)$ & $0.032 *$ & 1.921 & $0.025 * *$ & 2.242 & 0.005 & 0.761 \\
\hline$\Sigma \Delta \log \left(V A_{t-j}\right)$ & $0.289 * * *$ & 2.656 & $0.208 * *$ & 2.079 & -0.012 & -0.148 \\
\hline Long-run elasticity & 0.260 & & 0.180 & & 0.012 & \\
\hline $\mathrm{CASH}_{\mathrm{t}}$ & 0.086 & 1.060 & $0.361 * * *$ & 4.166 & $0.386^{* * *}$ & 4.274 \\
\hline $\mathrm{CASH}_{\mathrm{t}-1}$ & $0.110 * * *$ & 3.036 & -0.044 & -1.644 & 0.000 & 0.012 \\
\hline $\mathrm{CASH}_{\mathrm{t}-2}$ & 0.024 & 1.221 & $-0.046 * * *$ & -2.880 & -0.001 & -0.041 \\
\hline $\mathrm{CASH}_{\mathrm{t}-3}$ & -0.025 & -1.265 & -0.018 & -1.394 & 0.008 & 0.591 \\
\hline $\mathrm{CASH}_{\mathrm{t}-4}$ & 0.005 & 0.238 & 0.014 & 1.042 & -0.020 & -1.537 \\
\hline$\Sigma C A S H_{t-j}$ & $0.200 * * *$ & 3.479 & 0.266 & 4.375 & $0.374 * * *$ & 6.826 \\
\hline Long-run elasticity & 0.180 & & 0.230 & & 0.365 & \\
\hline & statistic & p-value & statistic & $\mathrm{p}$-value & statistic & p-value \\
\hline No. of obs. & 14856 & & 25444 & & 88220 & \\
\hline No. of firms & 3040 & & 4648 & & 16954 & \\
\hline Sargan & 121.649 & 0.568 & 114.515 & 0.739 & 130.063 & 0.360 \\
\hline Wald - lag 4 & 13.609 & 0.009 & 26.003 & 0.000 & 6.849 & 0.144 \\
\hline $\mathrm{m} 1$ & -15.658 & 0.000 & -19.145 & 0.000 & -34.795 & 0.000 \\
\hline $\mathrm{m} 2$ & 1.351 & 0.177 & -1.782 & 0.075 & -1.873 & 0.061 \\
\hline
\end{tabular}

2nd step GMM Arellano-Bond estimates of the investment equation (4) over 1991-1998 the constant and time dummies are not shown

* significant at the $10 \%$ level; ** significant at the $5 \%$ level; *** significant at the $1 \%$ level

The results are presented in Tables 4 and 5. It is immediately clear that the former regression results in section 4.1. with respect to both the complete sample and the sample of small firms are to a large extent determined by the investment behaviour of small service firms. This is not surprising because, with more than 88,000 observations, they represent more than $50 \%$ of the entire sample. Small service firms seem in fact not to react to user cost changes and value added growth, but they do react strongly to 
contemporaneous cash flow changes. A $1 \%$ point rise in the cash flow/capital ratio leads to an increase in the investment rate of $0.38 \%$ point. Large service firms are different from small ones in that they react significantly to value added growth but much less to cash flow changes. Again, the investment dynamics for large service firms seem smoother than those for small ones; they react less to user cost fluctuations (although the coefficient is more significant). Both small and large service firms seem not to react to user cost changes (however, as will be seen below, this is not generally the case for all service sectors). We also performed a formal test along the same lines as above, by pooling small and large service firms and putting a dummy for large firms on the coefficients of each variable (for all its lags) sequentially. Table 6 presents the results. The reaction to cash flow changes of large service firms seems significantly much lower than for small service firms.

Table 6: test of significant differences between small and large firms

\begin{tabular}{l|ll|ll|lc}
\hline & \multicolumn{2}{|c}{ manufacturing } & \multicolumn{2}{c}{ construction } & \multicolumn{2}{c}{ services } \\
& coef & t-stat & coef & t-stat & coef & t-stat \\
\hline$\Sigma\left(\mathrm{I}_{\mathrm{t}-\mathrm{j}} / \mathrm{K}_{\mathrm{t}-\mathrm{j}-1}\right) . \mathrm{D}$ & $0.251 * * *$ & 3.971 & 0.006 & 0.075 & 0.069 & 1.624 \\
$\Sigma \Delta \log \left(\mathrm{UCC}_{\mathrm{t}-\mathrm{j}}\right) . \mathrm{D}$ & 0.020 & 0.327 & -0.099 & -1.187 & -0.041 & -1.231 \\
$\Sigma \Delta \log \left(\mathrm{VA}_{\mathrm{t}-\mathrm{j}}\right) . \mathrm{D}$ & $0.200 *$ & 1.699 & -0.127 & -0.843 & -0.030 & -0.282 \\
$\Sigma \mathrm{CASH} \mathrm{t}_{\mathrm{t}-\mathrm{j}} \mathrm{D}$ & -0.077 & -1.094 & -0.082 & -1.285 & $-0.212 * * *$ & -3.935 \\
\hline
\end{tabular}

2nd step GMM Arellano-Bond estimates of the ADL(4) model of investment augmented with dummies for large firms over 1991-1998. Four separate regressions are performed, each of which has a dummy on all lags of one variable. The dummy D equals 1 for large firms and zero for small firms. The table reports the sum of the coefficients of the interaction terms between the variable and the dummy

* significant at the $10 \%$ level; ** significant at the $5 \%$ level; *** significant at the $1 \%$ level

Large manufacturing firms have a smoother investment pattern and are more responsive to value added growth than are small manufacturing firms. The investment behaviour of large manufacturing firms seems to correspond to theoretical priors (Table 4). Large manufacturing firms react negatively to user cost changes ${ }^{14}$ and positively to value added growth and cash flow changes. Small manufacturing firms operate in a similar way, except for a stronger user cost effect and less smooth dynamics. Especially, the small difference in the reaction of both subgroups to cash flow changes is remarkable. This is clearly different from the service sector. Construction firms seem to act quite similarly to their counterparts in manufacturing, at least in the long run. Only the negative influence of value added growth at lags 3 and 4 for large construction firms is rather distinctive. This presumably reflects some kind of cyclical behaviour.

14 Although coefficients on past user cost are not significant for large manufacturing firms, the total effect is. This may be due to negative correlations between the coefficients. 
Although most of the existing literature focuses on large firms in the manufacturing sector, and often estimates a different specification (for instance, one usually proxies the user cost by fixed effects and time dummies), we try to make some comparisons with other empirical evidence for the EU. First, our finding of a stronger cash flow sensitivity and a less smooth investment pattern for small firms appears to be consistent with the evidence, provided in several papers, that small firms face stronger financial constraints. For instance, Kremp and Stöss (2000) find that in Germany small firms are more creditdependent than large firms. Guiso (1997) shows that the probability of being creditconstrained decreases with size for Italian high-tech firms. Tychon (1997) indicates that large Belgian firms rely less on bank debt, while small Belgian firms are dominated by internal financing. Vermeulen (2000) also obtains higher cash flow sensitivities for small firms.

Second, considering the sensitivity of large manufacturing industries to cash flow, our estimate is close to that of Bond et al (1997).

Third, our results show a higher cash flow sensitivity for large manufacturing firms than for large firms in other sectors. This finding seems to be in contrast with Deloof (1998) who argues that large traditional industries may be less financially constrained thanks to intra-group lending. Intra-group lending, for instance through a co-ordination centre, may in fact to some extent alleviate financial constraints on member firms. This has been shown by, among others, Barran and Peeters (1998), who estimate an investment equation for Belgian manufacturing firms, both for those affiliated and those not affiliated to a coordination centre. However since firms of the former type represent only a minor part of the total sample of large manufacturing firms (between 5 and $7 \%$ over the estimation period, although a considerable part of aggregate investment), their behaviour is unlikely to exert a substantial influence on the estimation results.

To check the robustness of our results with respect to outliers, we estimated the ADL(4) model for a sample trimmed according to another methodology. We trim over the same variables but consider a range of values defined by a multiple of the median absolute deviation from the median (MAD) rather than by the percentiles. This criterion is more robust to outliers and yields a more symmetric distribution; we adopted a conservative threshold ${ }^{15}$. The results are reported in Appendix B. Although the order of magnitude of

15 The sample is half the interpercentile sample, for all sectors and sizes. 
the coefficients may differ in the two samples, most of our conclusions remain valid. Focusing on the long-run elasticities, and considering all sectors jointly (see Table B.1), the coefficient on past investment is negative for small firms, and small firms are more sensitive to cash flow but insensitive to value added. Distinguishing across sectors (see Tables B.2 and B.3) the estimates indicate that (1) the sum of the coefficients on past investment rate is more negative for small firms, (2) the long-run elasticity of investment to user cost fluctuations is larger for small firms, and non-significant for small services, (3) the long-run elasticity of investment to value added fluctuations is higher for large firms, (4) the long-run cash flow sensitivity is higher for small firms. Furthermore, (5) construction is more sensitive to user cost fluctuations than other sectors, and (6) manufacturing is more sensitive to value added fluctuations than other sectors.

\subsection{Further breakdown by branches}

As our results in the previous section clearly indicate that there are significant differences in investment behaviour across sectors of the economy, we try to split up our sample further into subsectors. Our data set enables us to break down the above three broad sectors into 23 subsectors: (1) agriculture, (2) extraction, (3) food, (4) textiles, (5) wood, (6) paper, (7) refineries, (8) chemicals, (9) plastics, (10) non-metal, (11) metal, (12) machinery, (13) transport equipment, (14) other industries, (15) electricity, gas and water, (16) construction, (17) retail and wholesale trade, (18) hotels and restaurants, (19) transport and communications, (20) financial services, (21) real estate, leasing and other services to firms, (22) education, (23) other services.

In order to keep a sufficiently large number of firms and observations in each regression, we do not distinguish, in this section, between small and large firms. We exclude sectors with fewer than 200 firms, i.e. agriculture, extraction, plastics, refineries, transport equipment, education and other services

Table 7 below shows the total effect of each variable for each subsector separately ${ }^{16}$. The Sargan statistic accepts the model in all cases except for retail and wholesale trade; we therefore omit this sector from the analysis. The statistic $\mathrm{m} 1$ has a close-to-zero p-value, thus rejecting an I(1) process of the residuals, and there is no second order serial

16 For the sake of brevity, we do not present full results. These are available on request. 
correlation in the residuals (m2 statistic), except for paper, and to a lesser extent, construction ${ }^{17}$.

Table 7: ADL(4) model of investment by branch : overall effects

\begin{tabular}{|c|c|c|c|c|c|c|}
\hline & $\Sigma\left(\mathrm{I}_{\mathrm{t}-\mathrm{j}} / \mathrm{K}_{\mathrm{t}-\mathrm{j}-1}\right)$ & $\begin{array}{l}\text { long-run } \\
\text { elasticity to } \\
\text { UCC }\end{array}$ & $\begin{array}{l}\text { long-run } \\
\text { elasticity to } \\
\text { VA }\end{array}$ & $\begin{array}{l}\text { long-run } \\
\text { elasticity to } \\
\mathrm{CASH}\end{array}$ & $\begin{array}{c}\text { No. of } \\
\text { obs. }\end{array}$ & $\begin{array}{l}\text { No. of } \\
\text { firms }\end{array}$ \\
\hline \multicolumn{7}{|l|}{ Manufacturing } \\
\hline Food & $-0.096 * * *$ & -0.061 & 0.115 & $0.374 * * *$ & 4360 & 797 \\
\hline Textiles & $-0.077 * * *$ & -0.063 & $0.124 *$ & $0.056 *$ & 3601 & 661 \\
\hline Wood & $-0.337 * *$ & -0.054 & 0.105 & $0.393 * * *$ & 807 & 230 \\
\hline Paper & $-0.213 * * *$ & $-0.218 * * *$ & 0.145 & $0.111 * * *$ & 4096 & 789 \\
\hline Chemicals & $-0.406 * * *$ & $-0.091 * * *$ & $0.267 * * *$ & $0.092 * * *$ & 1206 & 225 \\
\hline Non-metal & $-0.100 * * *$ & $-0.098 * * *$ & 0.100 & $0.240 * * *$ & 2424 & 412 \\
\hline Metal & $-0.310 * * *$ & -0.052 & $0.305 * * *$ & $0.608 * * *$ & 1851 & 452 \\
\hline Machinery & $-0.282 * * *$ & -0.069 & $0.333 * * *$ & $0.167 * * *$ & 2809 & 540 \\
\hline Other industries & $-0.431 * *$ & -0.039 & -0.018 & $0.613 * *$ & 1037 & 270 \\
\hline Construction & $-0.151 * * *$ & $-0.117 *$ & $0.182 * *$ & $0.206 * * *$ & 28322 & 5095 \\
\hline \multicolumn{7}{|l|}{ Services } \\
\hline Hotels and restaurants & $-0.115 * * *$ & $-0.162 * *$ & 0.053 & $0.263 * * *$ & 4764 & 933 \\
\hline $\begin{array}{l}\text { Transport and } \\
\text { communications }\end{array}$ & $-0.161 * * *$ & $-0.131 * *$ & $0.286 * * *$ & $0.226 * * *$ & 12096 & 2074 \\
\hline Financial services & $-0.362 * * *$ & -0.010 & 0.091 & 0.053 & 4005 & 809 \\
\hline $\begin{array}{l}\text { Real estate, leasing and } \\
\text { other services to firms }\end{array}$ & $-0.159 * * *$ & -0.068 & $0.224 * * *$ & $0.072 * * *$ & 20240 & 4001 \\
\hline Other services & $-0.175 * * *$ & $-0.181 * * *$ & $0.319 * * *$ & $0.052 * * *$ & 6599 & 1338 \\
\hline
\end{tabular}

2nd step GMM Arellano-Bond estimates of the investment equation (4) over 1991-1998 figures represent the long-run elasticity of investment with respect to the variable except for $\Sigma\left(\mathrm{I}_{\mathrm{t}-\mathrm{j}} / \mathrm{K}_{\mathrm{t}-\mathrm{j}-1}\right)$, which is the sum of the coefficients on past investment * significant at the $10 \%$ level; ** significant at the $5 \%$ level; *** significant at the $1 \%$ level

All coefficients vary substantially across sectors. The effect of past investment varies from -0.4 (in other industries and chemicals) to -0.1 (in textiles, food and non-metal). The longrun elasticity with respect to value added is greater for capital-intensive subsectors such as machinery, metal, chemicals, transport and communications than for services, especially financial services and hotels and restaurants. One exception is construction, which has a medium-to-high elasticity in spite of a low capital/labour ratio. The long-run elasticity to cash flow ranges from 0.6 (in metal and other industries) to 0.1 (in paper, chemicals,

$17 \mathrm{~m} 1$ is a specification test for first order serial correlation of the residuals. Since, equation (4) is estimated in first difference, no first order serial correlation in the residuals implies that the error term of equation (4) has a unit root, and that our estimates might suffer from a spurious regression problem. So, the residuals must be serially correlated; the estimation procedure corrects standard errors for this. $\mathrm{m} 2$ is a specification test for second order serial correlation. Again, since equation (4) is estimated in first difference, no second order serial correlation in the residuals garanties no first order serial correlation of the eror term of equation (4), i.e. that the model is correctly specified. See Arrelano and Bond (1991) for an exposition. 
textiles, financial services, real estate, leasing and other services to firms and other services).

Finally, the long-run elasticity with respect to the user cost varies substantially across sectors. In a large number of cases, the total effect is not significant. This is the case, in particular, for service sectors, which confirm the results of the previous section ${ }^{18}$. It also applies for some manufacturing industries. As the sample is much smaller at this disaggregated level, which may lead to a loss of accuracy, we focus on the point estimates. The user cost elasticity reflects the elasticity of substitution between capital and labour; it is more negative for capital-intensive sectors (such as paper, and to a lesser extent, transport and communications) than for labour-intensive sectors (such as financial services). There are two exceptions to this: construction and hotels and restaurants. Excluding construction, the correlation between the total user cost effect and the capital/labour ratio is equal to $-43 \% 19$.

Gérard and Verschueren (2000) also find differences in long-run elasticity to user cost across Belgian industries, and they also find that textiles and wood have a medium-to-low long-run elasticity, although the order of magnitude differs from our results ${ }^{20}$.

\section{Effects of monetary policy on investment}

As already mentioned, in order to investigate the effects of monetary policy on investment, we proceed in two steps. In the previous section we estimated an investment equation. Here, we calculate the elasticity of the user cost of capital with respect to the market interest rate and the elasticity of cash flow with respect to the market interest rate. We ignore potential interest rate effects on value added. The long-run elasticity of capital to the market interest rate is then equal to:

$$
\begin{aligned}
& \frac{\mathrm{dK}_{\mathrm{it}}}{\mathrm{dr}_{\mathrm{t}}} \cdot \frac{\mathrm{r}_{\mathrm{t}}}{\mathrm{K}_{\mathrm{it}}}=\frac{\mathrm{dK}_{\mathrm{it}}}{\mathrm{dUCC}_{\mathrm{it}}} \cdot \frac{\mathrm{UCC}_{\mathrm{it}}}{\mathrm{K}_{\mathrm{it}}} \cdot \frac{\mathrm{dUCC}_{\mathrm{it}}}{\mathrm{di}_{\mathrm{it}}} \cdot \frac{\mathrm{i}_{\mathrm{it}}}{\mathrm{UCC}_{\mathrm{it}}} \cdot \frac{\mathrm{di}_{\mathrm{it}}}{\mathrm{dr}_{\mathrm{t}}} \cdot \frac{\mathrm{r}_{\mathrm{t}}}{\mathrm{i}_{\mathrm{it}}} \\
& +\frac{\mathrm{dK}_{\mathrm{it}}}{\mathrm{dCash}_{\mathrm{it}}} \cdot \frac{\mathrm{Cash}_{\mathrm{it}}}{\mathrm{K}_{\mathrm{it}}} \cdot \frac{\mathrm{dCash}_{\mathrm{it}}}{\mathrm{di}_{\mathrm{it}}} \cdot \frac{\mathrm{i}_{\mathrm{it}}}{\operatorname{Cash}_{\mathrm{it}}} \cdot \frac{\mathrm{di}_{\mathrm{it}}}{\mathrm{dr}_{\mathrm{t}}} \cdot \frac{\mathrm{r}_{\mathrm{t}}}{\mathrm{i}_{\mathrm{it}}}
\end{aligned}
$$

18 An additional analysis shows that this remains valid if we distinguish between small and large firms.

19 This correlation is significant at the $12.5 \%$ level.

20 They perform a cointegration analysis on industry-level time series data over the period 1953-1996. They do not include cash flow in the investment equation. 
where $\mathrm{i}_{\mathrm{it}}$ is the apparent interest rate faced by the firm and $\mathrm{r}_{\mathrm{t}}$, the three-month market interest rate. Each term of the right-hand side of this expression consists of three elements. The first element is the long-run elasticity of capital with respect to the user cost (cash flow) and is given by the estimates in the previous section. The second element represents the elasticity of the user cost (cash flow) with respect to the apparent interest rate, and this can be derived analytically (from the definitions of the user cost and cash flow given in Appendix A.2):

$$
\begin{aligned}
& \frac{\mathrm{dUCC}_{\mathrm{it}}}{\mathrm{di}_{\mathrm{it}}} \cdot \frac{\mathrm{i}_{\mathrm{it}}}{\mathrm{UCC}_{\mathrm{it}}}=\frac{\mathrm{i}_{\mathrm{it}}}{\mathrm{i}_{\mathrm{it}}+\delta_{\mathrm{i}}-\left(1-\delta_{\mathrm{i}}\right) \cdot \frac{\Delta \mathrm{P}_{\mathrm{st}+1}^{\mathrm{I}}}{\mathrm{P}_{\mathrm{st}}^{\mathrm{I}}}} \\
& \frac{\mathrm{dCash}_{\mathrm{it}}}{\mathrm{di}_{\mathrm{it}}} \cdot \frac{\mathrm{i}_{\mathrm{it}}}{\mathrm{Cash}_{\mathrm{it}}}=\frac{\text { int erest ch arg es }}{\text { Cash }_{\text {it }}}
\end{aligned}
$$

where $\delta_{\mathrm{i}}$ is the firm-specific depreciation rate and $\mathrm{P}_{\text {st }}^{\mathrm{I}}$ the sector-specific deflator on gross capital formation. If we accept that the user cost and cash flow definitions hold on average, we can approximate the elasticity by taking mean values (by sector and size) of expressions (6) and (7).

Finally, with respect to the third element, the elasticity of the apparent interest rate to the market interest rate, given that the sample period does not exceed fifteen years, we have to recognise that the time dimension of the data is too short to capture long-run or even medium-run trends. Thus, rather than estimating this elasticity, an alternative procedure consists in fixing it to some arbitrarily chosen value. We postulate it to be 1 , which should correspond to its long-run equilibrium value. By doing so, on the one hand, we avoid unreliable estimates related to low degrees of freedom estimation, but, on the other hand, we do not capture any heterogeneity across sectors and sizes ${ }^{21}$. Fortunately, although the precise value of this elasticity affects the size of the total effect of interest rate changes on the capital stock, it does not alter the qualitative conclusions: i.e. the sign of the total effect and its ranking across sectors remain unchanged, as long as the elasticity is constant acriss sectors.

This procedure might, however, have some implications for the precise meaning of the effects we are measuring. Usually it is considered that the effect which operates through the user cost, belongs to the interest rate channel', whereas the effect through the cash flow variable is related to the 'credit channel'. Since we do not estimate the elasticity of the

21 For example, Valderrama (2001) shows that banks do not cut credit but increase its cost for firms for which they are the house bank. 
apparent interest rate with respect to the market interest rate, but just postulate that it is the unitary value, we do not isolate the pure effects of the policy-controlled interest rate from other influences, such as the financial structure of the firm. We therefore need to treat the labels of the different effects with some caution.

Table 8 reports the elasticity results of the capital stock with respect to the market interest rate, summarising the results for the three sectors and the two sizes that we consider in section 4.2. As far as the interest rate channel is concerned, small firms cut their capital stock more strongly following an interest rate increase than large firms do; this feature applies for both the manufacturing and the construction sectors. When large firms of several sectors are compared, the results show that construction firms are more sensitive to interest rate fluctuations than manufacturing firms. For services the effect is positive and non-significant in both size subgroups.

The next three lines of Table 8 show the elasticity of capital with respect to the market interest rate through the cash flow variable (the credit channel) for the broad sectors described in section 4.2. They show that investment by small firms is more sensitive than that by large firms, in particular in the manufacturing sector. The effect is again close to zero in the service sector. This result is mainly due to the fact that interest payments seem to have little influence on service firms. In other words, the elasticity of cash flow with respect to the apparent interest rate is low in service firms.

Finally, combining both channels, the last three lines of Table 8 show the total elasticity of the capital stock with respect to the market interest rate. Obviously, the same conclusions remain valid. Small firms reduce their capital stock to a greater extent following a monetary contraction, especially in the manufacturing sector. The manufacturing and construction sectors are the most sensitive to interest rate fluctuations, while services are almost unaffected. 
Table 8: Total elasticity of capital with respect to the market interest rate

\begin{tabular}{|c|c|c|c|c|}
\hline & all firms & manufacturing & construction & services \\
\hline \multicolumn{5}{|c|}{ through the user cost (interest rate channel) } \\
\hline large firms & 0.002 & -0.005 & -0.011 & 0.001 \\
\hline small firms & 0.004 & -0.018 & -0.015 & 0.004 \\
\hline all firms & 0.005 & & & \\
\hline \multicolumn{5}{|c|}{ through cash flow (credit channel) } \\
\hline large firms & -0.027 & -0.058 & -0.050 & -0.007 \\
\hline small firms & -0.123 & -0.082 & -0.054 & 0.004 \\
\hline all firms & -0.110 & & & \\
\hline \multicolumn{5}{|c|}{ total elasticity of capital with respect to the market interest rate } \\
\hline large firms & -0.024 & -0.063 & -0.060 & -0.006 \\
\hline small firms & -0.119 & -0.100 & -0.069 & 0.008 \\
\hline all firms & -0.105 & & & \\
\hline
\end{tabular}

source: authors' calculations

the effect of the interest rate channel is computed combining equations (5) and (6) with $\mathrm{dK}_{\mathrm{it}} / \mathrm{dCash}_{\mathrm{it}}$ set to zero.

the effect of the credit channel is computed combining equations (5) and (7) with $\mathrm{dK}_{\mathrm{it}} / \mathrm{dUCC}_{\mathrm{it}}$ set to zero.

Our outcome for the Belgian manufacturing sector is consistent with Wesche's (2000) results for Austria, or with Ehrmann's (2000) conclusions, derived from a structural VAR analysis, for Germany. Both papers show that small firms suffer more from a monetary contraction than large firms. Also the fact that investment by construction firms reacts more strongly to interest changes is not too surprising, as demand in this sector is interestsensitive.

Other papers of the Monetary Transmission Network project also highlight distributional effects of monetary policy. Except for France, the results confirm our findings that small firms are more strongly affected by monetary policy than large firms are. For Italy, Gaiotti and Generale (2001) find, as we do, that small firms have greater long-run elasticity with respect to the user cost and cash flow. The same result applies for firms with less tangible assets (which implies less collateral). For France, Chatelain and Tiomo (2001) obtain evidence that equipment goods firms, firms with a low trade credit share and risky firms are more sensitive to cash flow than other firms. For Germany, von Kalckreuth (2001) show that firms with a high credit rating are less sensitive to cash flow and more sensitive to the user cost, and that small firms are more sensitive to the user cost (although not significantly so). For Austria, the results of Valderrama (2001) reveal that firms which have a house bank are less sensitive to cash flow but more sensitive to the user cost. Further, this author's point estimates suggest that young firms may be more sensitive to the user cost and cash flow. For Luxembourg, Lünnemann and Mathä (2001) find that young firms are more sensitive to cash flow, the user cost and sales growth. 
We also perform an analogous exercise for the 15 branches analysed in section 4.3. Table 9 summarises these results. For the interest rate channel, the elasticity of capital to the market interest rate varies from -0.07 to around zero. It is more negative for capitalintensive sectors than for labour-intensive sectors. This negative relationship is plotted in Figure 1. Excluding construction, the correlation coefficient between this elasticity, $\varepsilon_{\mathrm{K}, \mathrm{r}}$ and the capital/labour ratio, $\mathrm{K} / \mathrm{L}^{22}$, is equal to $-42 \%{ }^{23}$. The effects of the credit channel are stronger. The elasticity of capital with respect to interest rate changes through cash flow ranges from -0.18 (for wood and metal) to -0.01 (for financial services and other services). Finally the total effect of the interest rate and credit channels ranges from -0.20 to a closeto-zero value (especially for services).

Table 9: Total elasticity of capital with respect to the market interest rate by branch

\begin{tabular}{lcccc}
\hline & $\begin{array}{c}\text { interest rate } \\
\text { channel }\end{array}$ & credit channel & total effect & K/L \\
\hline Manufacturing & -0.020 & -0.100 & -0.121 & 46 \\
Food & -0.033 & -0.026 & -0.059 & 26 \\
Textiles & -0.024 & -0.152 & -0.176 & 37 \\
Wood & -0.069 & -0.037 & -0.106 & 52 \\
Paper & -0.039 & -0.031 & -0.070 & 63 \\
Chemicals & -0.031 & -0.072 & -0.103 & 50 \\
Non-metal & -0.019 & -0.176 & -0.196 & 36 \\
Metal & -0.025 & -0.031 & -0.056 & 27 \\
Machinery & -0.012 & -0.086 & -0.098 & 32 \\
Other industries & -0.039 & -0.063 & -0.102 & 20 \\
Construction & & & & \\
\hline Services & -0.046 & -0.026 & -0.072 & 29 \\
Hotels and restaurants & -0.037 & -0.039 & -0.076 & 61 \\
Transport and & -0.003 & -0.007 & -0.010 & 32 \\
communications & -0.021 & -0.020 & -0.041 & 42 \\
Financial services & & & & \\
Real estate, leasing and & -0.045 & -0.014 & -0.059 & 48 \\
\hline other services to firms & & & & \\
Other services & & &
\end{tabular}

source: authors' calculations

the effect of the interest rate channel is computed combining equations (5) and (6) with $\mathrm{dK}_{\mathrm{it}} / \mathrm{dCash}_{\mathrm{it}}$ set to zero.

the effect of the credit channel is computed combining equations (5) and (7) with $\mathrm{dK}_{\mathrm{it}} / \mathrm{dUCC}_{\mathrm{it}}$ set to zero.

22 The capital/labour ratio is constructed as follows. The real capital stock is computed using the perpetual inventory method. It is expressed in millions of 1995 BEF expressed in euros. Employment data collected in annual accounts represent the number of employees (not expressed in full-time-equivalent), averaged (over the year) before 1996, and the end of the year since 1996.

23 The correlation is significant at the $12.5 \%$ level. 
Figure 1: Elasticity of capital with respect to the market interest rate (through the interest rate channel) and capital intensity for 14 branches

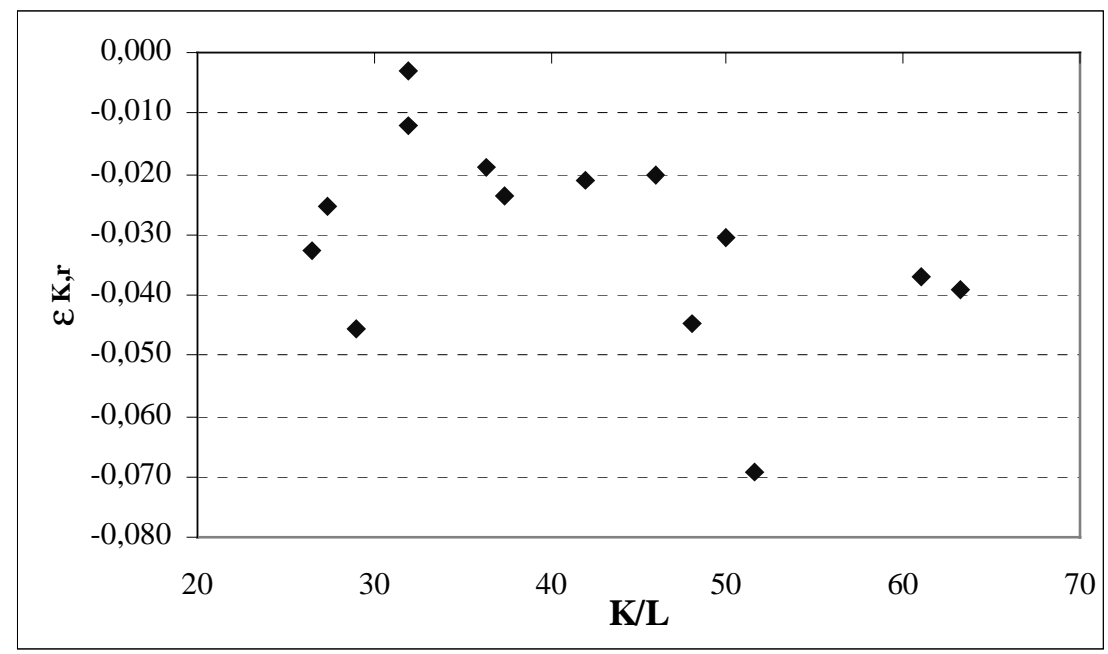

\section{Conclusion}

This paper investigates some of the effects of monetary policy on firms' investment behaviour. In particular, we confine our analysis to effects that operate through changes in the user cost of capital and cash flow, and that, with some caution, can be identified with the usual interest rate and crredit channels of monetary policy.

The analysis relies on the use of a comprehensive database of Belgian firms over the period 1985-1998, covering all sectors of economic activity, and firms of all sizes. This database enables us to investigate this issue for each sector and for large and small firms separately. Taking into account the heterogeneity among firms enables us to avoid possible aggregation biases and to find evidence for distributional effects of monetary policy across sectors and sizes.

We proceed in two steps. First, we estimate an ADL(4) version of a reduced-form investment equation, derived from the neo-classical model, including the firm-specific user cost of capital and augmented with cash flow. This equation is estimated with the Arellano and Bond (1991) GMM procedure. Second, we compute the elasticity of the firm-specific user cost of capital and the cash flow variable to the policy-controlled interest rate.

With respect to the first step, we begin by estimating the model for the complete sample. The results suggest that investment is not a smooth process, and that the user cost has no 
significant role to play, in contrast with value added and cash flow. Then, we split our sample into large and small firms. This procedure can be justified by several considerations. First, as the vast majority of the firms in our sample are small, large firms carry less weight in a pooled regression, and hence their behaviour will be obscured. In addition, it has been argued that small and large firms might have quite different investment behaviour : for instance, small firms are likely to be more credit-constrained. Overall, our results indicate, in this exercise, that large firms' investment is smoother, depends more on value added growth, and less on cash flow. Small firms' investment depends heavily on cash flow (which indicates that they may be more financially constrained) but not on value added. The user cost does not seem to be important for investment by either large or small firms' investment

Next, we split our sample further into three broad sectors of the economy. From the results it is immediately clear that the previous regression outcomes are to a large extent determined by the investment behaviour of small service firms. Both small and large service firms seem not to react to user cost changes. Small service firms do not react to value added growth either, but they do respond strongly to contemporaneous cash flow changes. Large service firms are different from small ones in that they react significantly to value added growth but much less to cash flow changes. Again, the investment dynamics for large service firms seem smoother than for small ones. The investment behaviour of manufacturing and construction firms seems to correspond to theoretical priors. They react negatively to user cost changes, and positively to value added growth and cash flow changes. Small firms in these sectors show stronger user cost effect and less smooth dynamics.

Since our results indicate that there are significant differences in investment behaviour across sectors of the economy, we try to split up our sample further into subsectors. All coefficients vary substantially across sectors, as would be expected. The long-run elasticity with respect to value added is, in general, greater for capital-intensive industries. The long-run elasticity with respect to the user cost is, in a large number of cases, not significant. This is true, in particular, of service sectors, which confirm the results of the previous sample split.

We then start the second step of our analysis and calculate the elasticity of the user cost of capital and the elasticity of the cash flow with respect to the market interest rate. We finally combine these computations with the estimated user cost and cash flow effects in the investment equation, to obtain an idea of the total interest-rate sensitivity of capital. 
The magnitude of the credit channel seems more important than that of the interest rate channel. Small firms are more sensitive than large firms. Large construction firms have a higher elasticity than large manufacturing firms. Services are almost unaffected.

In sum, the results support, in general, the hypothesis of an interest rate and credit channel in Belgium. The impact of these channels differs across sectors and sizes. We can thus conclude that monetary policy produces distributional effects.

\section{References}

Arellano, M. and S. Bond (1991) "Some tests of specification for panel data: Monte Carlo evidence and an application to employment equations", Review of Economic Studies, 58, 277-297

Barran, F. and M. Peeters (1998) "Internal finance and corporate investment. Belgian evidence with panel data", Economic Modelling, 15, 67-89

Bond, S. and C. Meghir (1994) "Dynamic investment models and the firm's financial policy", Review of Economic Studies, 61, 197-227.

Bond, S., Elston, J., Mairesse, J. and B. Mulkay (1997) "Financial factors and investment in Belgium, France, Germany and the United Kingdom. A comparison using company panel data", NBER working paper No. 5900

Chatelain, J.-B. and A. Tiomo (2001) "Investment, the cost of capital and monetary policy in the nineties in France: a panel data investigation", ECB Working Paper, $\mathrm{n}^{\circ} 107$

Chatelain, J.-B. and J.-C. Teurlai (2000) Comparing several specifications of financial constraints and adjustment costs in investment Euler equations, Banque de France, mimeo

Deloof, M. (1998) "Internal capital markets, bank borrowing, and financing constraints. Evidence from Belgian firms", Journal of Business Finance and Accounting, 25(7), 945-968

Doms, M. and T. Dunne (1998) "Capital adjustment patterns in manufacturing plants", Review of Economic Dynamics, 1(2), 409-429

Ehrmann, M. (2000) "Firm size and monetary policy transmission: evidence from German business survey data", ECB working paper No. 21.

Eisner, R. and M.F. Nadiri (1968) "Investment behaviour and neo-classical theory", Review of Economics and Statistics, 50, 369-388

Fazzari S., Hubbard G.R. and B.C. Petersen (1988) "Financing constraints and corporate investment", Brookings Papers on Economic Activity, 1, 141-195 
Gaiotti, E. and A. Generale (2001) "Does monetary policy have asymmetric effects? A look at the investment decisions of Italian firms", ECB Working Paper, $\mathrm{n}^{\circ} 111$

Gérard, M. and F. Verschueren (2000) "The neoclassical synthesis of investment behaviour and the co-integration challenge, an experimentation with Belgian industry data", Cahiers Economiques de Bruxelles, 167, 299-344.

Guiso, L. (1997) "High-tech firms and credit rationing", CEPR discussion paper No. 1696.

Hubbard, G.R., Kashyap, A.K. and T.M. Whited (1995) "Internal finance and firm investment", Journal of Money, Credit and Banking, 27, 683-701

Jensen, M. and W. Meckling (1976) "Theory of the firm : managerial behaviour, agency costs, and ownership structure", Journal of Financial Economics, 1, 305-360

Jorgenson, D.W. (1963) "Capital theory and investment behaviour", American Economic Review, 53(2), 247-259

Kaplan, S.N. and L. Zingales (1997) "Do investment cash flow sensitivities provide useful measures of financing constraints?", Quarterly Journal of Economics, 112(1), 169215.

Kremp, E. and E. Stöss (2000), Estimating the borrowing behaviour of French and German firms, mimeo

Lucas, R.E. (1976) "Econometric policy evaluation : a critique" in Carnegie-Rochester Conference Series Public Policy

Lünnemann, P. and T. Mathä (2001) "Monetary transmission: empirical evidence from Luxembourg firm-level data", ECB Working Paper, ${ }^{\circ} 112$

Mairesse, J., Hall, B.H. and B. Mulkay (1999) "Firm level investment in France and the United States: an exploration of what we have learned in twenty years", NBER working paper No. 7437

Mörttinen, L. (2000) Credit channel of monetary policy and inventory investment, mimeo

Myers, S.C. and M.S. Majluf (1984) "Corporate financing and investment decisions when firms have information that investors do not have", Journal of Financial Economics, 13, 187-221

Pesaran, M.H., Shin, Y. and R.P. Smith (1999) "Pooled mean group estimator of dynamic heterogeneous panels", Journal of the American Statistical Association, 94, 621-634

Stiglitz, J. and A. Weiss (1981) "Credit rationing in markets with imperfect information" American Economic Review, 71, 393-410

Tychon, P. (1997) "The structure of corporate finance in Belgium: an empirical investigation", IRES discussion paper No. 9719

Valderrama, M. (2001) "Credit channel and investment behavior in Austria: a microeconometric approach", ECB Working Paper, n 109 
Vermeulen, P. (1998) Detecting the influence of financing constraints on fixed investment, mimeo

Vermeulen, P. (2000) "Business fixed investment: evidence of a financial accelerator in Europe", ECB working paper No. 37

Verschueren I. and M. Deloof (1999) "Intragroup debt, intragroup guarantees, and the capital structure of Belgian firms", Universiteit Gent working paper No. 99/73

von Kalckreuth, U. (2001) "Monetary transmission in Germany: new perspectives on finance constraints and investment spending", ECB Working Paper, ${ }^{\circ} 110$

Wesche, K. (2000) "Is there a credit channel in Austria? The impact of monetary policy on firms' investment decisions", National Bank of Austria working paper No. 41

Whited, T.M. (1992) "Debt, liquidity constraints and corporate investment : evidence from panel data", Journal of Finance, 47, 1425-1460 


\section{Appendix A : Data}

\section{A1. Sample selection and representativeness of the sample}

From the original annual accounts database of the National Bank of Belgium we construct our sample according to several criteria, as described in Table A.1. In a first step we select the profit-maximising firms. We therefore exclude firms that do not belong to the market sector. To be more specific, we eliminate annual accounts of foreign and public companies and of non-profit associations. This leaves us with $99.7 \%$ of the initial sample. Second, we retain only the firm-years with strictly positive total assets, fixed assets and depreciation rate. Annual accounts that do not meet this requirement may be consistent purely accounting-wise, but are usually submitted by firms that are close to bankruptcy. The remaining observations represent around $90 \%$ of the initial sample.

Third, we impose that all variables (investment/capital ratio, cash flow/capital ratio, user cost of capital and value added) are available, not only in levels but also in first differences. This means that for each firm there must be at least two consecutive annual accounts and that user cost of capital and value added variables must be strictly positive, since they appear in logarithm form in the equation. We call this our first reference sample. It already represents less than $50 \%$ of the initial sample. Next, we trim the variables for outliers by dropping the first and the 99th percentile of the level and first difference. We perform the trimming on a year by year basis, and for small and large firms separately. Our procedure is stricter than the standard practice in the literature, where outlier selection is done on the whole sample, or, at best, on a yearly basis only. Size is, however, the outstanding feature, which can substantially influence the trimming results ${ }^{24}$. Section A.2 gives an idea of the distributional differences according to size. Finally, we select only those firms with enough consecutive annual accounts to enable the ADL(4) model to be estimated. Because the model is estimated in differences, we need at least seven consecutive years. This leaves us with around $12 \%$ of the initial sample.

24 As we estimate a specific investment equation for each size/industry separately, an even more restrictive option would be to perform the trimming accordingly. 
Table A.1: Consecutive windows for the sample selection over 1991-1998

\begin{tabular}{lrr}
\hline selection criteria & $\begin{array}{r}\text { number of } \\
\text { observations }\end{array}$ & in \% of total \\
\hline 1. all firms & 1544105 & $100.0 \%$ \\
2. profit-maximising firms & 1539150 & $99.7 \%$ \\
3 (b) strictly positive total assets and total liabilities & 1539005 & $99.7 \%$ \\
3 (b) strictly positive real fixed assets & 1399056 & $90.6 \%$ \\
3 (c) strictly positive depreciation rate & 1390863 & $90.1 \%$ \\
4 (a) available $(\Delta)$ investment/capital ratio & 808413 & $52.4 \%$ \\
4 (b) available $(\Delta)$ and positive user cost of capital & 770957 & $49.9 \%$ \\
4 (c) available $(\Delta)$ cash flow/capital ratio & 770943 & $49.9 \%$ \\
4 (d) available $(\Delta)$ and positive value added & 740998 & $48.0 \%$ \\
5. trimming & 658643 & $42.7 \%$ \\
6 (a) sample to estimate an ADL(2) & 307984 & $19.9 \%$ \\
6 (b) sample to estimate an ADL(3) & 242185 & $15.7 \%$ \\
6 (c) sample to estimate an ADL(4) & 190554 & $12.3 \%$ \\
\hline
\end{tabular}

Next, we will evaluate the representativeness of our final sample. Table A.2. gives a first indication. It shows that the remaining firms represent around $40 \%$ of the profitmaximising sample (after selection step 2), in terms of both value added and employment, and $20 \%$ of aggregate economic activity as shown in the national accounts ${ }^{25}$.

Table A.2 : Representativeness of the final sample (1) over 1991-1998

\begin{tabular}{ccc} 
in \% of national accounts $\mathbf{( 2 )}$ & $\begin{array}{c}\text { in \% of the profit-maximising } \\
\text { sample (3) }\end{array}$ \\
\hline value added & value added & employment \\
\hline 0.00 & 4.29 & 4.08 \\
46.04 & 47.72 & 45.99 \\
44.89 & 65.86 & 64.98 \\
46.22 & 45.73 & 45.16 \\
\hline 31.61 & 49.64 & 47.68 \\
\hline 16.14 & 40.22 & 41.63 \\
\hline 0.01 & 10.83 & 21.13 \\
\hline 19.94 & 43.88 & 43.67 \\
\hline
\end{tabular}

(1) Final sample refers to the sample in step 6(c) in table A.1.

(2) Aggregation of the final sample value added over value added reported in the national accounts (source: the Institute for National Accounts)

(3) Aggregated value added (employment) over the final sample, over aggregated value added (employment) of the sample of profit-maximising firms; the profit-maximising sample refers to the sample in step 2 in Table A.1.

Since, comparing the final sample with the profit-maximising sample, the percentage of observations of the final sample in the sample of profit-maximising firms $(12 \%)$ is smaller than the percentage of value added or employment of the final sample in the profitmaximising sample (44\%), there might be a bias towards large firms. However, the

25 Note that in the final and profit-maximising sample we included refineries in the manufacturing sector rather than in energy. 
number of small firms still remains quite large. As shown in Table A.3, more than $40 \%$ of firms hire at most five employees. Note that the proportion of large firms is highest in the manufacturing sector.

Table A.3 : Number of employees in the final sample over 1991-1998

\begin{tabular}{l|rrrr}
\hline & all firms & manufacturing & construction & services \\
\hline average & 34.06 & 86.91 & 19.42 & 24.35 \\
median & 7 & 16 & 7 & 6 \\
\hline fewer than 1 employee & $10.79 \%$ & $4.41 \%$ & $7.32 \%$ & $13.21 \%$ \\
fewer than 5 employees & $44.05 \%$ & $24.13 \%$ & $40.46 \%$ & $49.78 \%$ \\
fewer than 10 employees & $62.84 \%$ & $39.98 \%$ & $61.67 \%$ & $68.55 \%$ \\
fewer than 50 employees & $92.38 \%$ & $79.66 \%$ & $93.43 \%$ & $95.11 \%$ \\
\hline
\end{tabular}

fewer than $\mathrm{x}$ employees stands for the percentage of firms with less than $\mathrm{x}$ employees,

Comparing value added and employment sector shares of the national accounts with those of both samples, Table A.4. indicates that manufacturing and construction may be somewhat over represented in our final sample.

Table A.4 : Comparison of the relative importance of sectors in 1995 in the national accounts, in the profit-maximising sample and in the final sample

\begin{tabular}{|c|c|c|c|c|c|c|}
\hline \multirow[b]{3}{*}{ agriculture } & \multicolumn{3}{|c|}{ sector share in value added } & \multicolumn{3}{|c|}{ sector share in employment } \\
\hline & $\begin{array}{c}\text { national } \\
\text { accounts }(1)\end{array}$ & $\begin{array}{l}\text { profit- } \\
\text { maximising } \\
\text { sample }\end{array}$ & final sample & $\begin{array}{c}\text { national } \\
\text { accounts }(2)\end{array}$ & $\begin{array}{l}\text { profit- } \\
\text { maximising } \\
\text { sample }\end{array}$ & final sample \\
\hline & 1.5 & 0.5 & 0.0 & 2.5 & 0.7 & 0.0 \\
\hline industries & 21.7 & 44.5 & 50.1 & 19.7 & 38.4 & 41.4 \\
\hline energy & 2.9 & 4.2 & 6.4 & 0.9 & 1.7 & 2.7 \\
\hline $\begin{array}{l}\text { manufacturin } \\
\mathrm{g}\end{array}$ & 18.9 & 40.4 & 43.8 & 18.8 & 36.7 & 38.8 \\
\hline construction & 4.8 & 7.1 & 7.7 & 6.6 & 10.0 & 10.9 \\
\hline $\begin{array}{l}\text { commercial } \\
\text { services }\end{array}$ & 52.2 & 47.7 & 42.2 & 51.9 & 50.7 & 47.6 \\
\hline others & 19.8 & 0.1 & 0.0 & 19.4 & 0.2 & 0.0 \\
\hline
\end{tabular}

(1) source:the Institute for National Accounts

(2) source: the National Office for Employment

Finally, since use of a dynamic model and estimation in first differences is very costly in terms of the number of observations lost, there might also be a concern that we are only analysing the investment behaviour of mature firms. We therefore calculated some basic statistics for the final sample and the profit-maximising sample. The median and median absolute deviation from the median shown in Table A.5 show that the distribution of the major variables in both samples is very close. Of course, the final sample has a lower dispersion than the initial one owing to the focus on the interpercentile range, and its is more symmetric for all variables, especially for the investment rate and cash flow. But the 
median is almost unaffected. We can thus conclude that our selection has not introduced a pronounced representation bias.

Table A.5: Comparison of the median and the median absolute deviation from the median (MAD) in the profit-maximising and final sample

\begin{tabular}{|c|c|c|c|c|c|c|c|c|}
\hline & \multicolumn{4}{|c|}{ Investment rate } & \multicolumn{4}{|c|}{ Investment growth rate } \\
\hline & \multicolumn{2}{|c|}{ median } & \multicolumn{2}{|c|}{ MAD } & \multicolumn{2}{|c|}{ median } & \multicolumn{2}{|c|}{ MAD } \\
\hline & $\Pi \max$ & final & $\Pi \max$ & final & $\Pi \max$ & final & $\Pi \max$ & final \\
\hline 1991 & 0.15 & 0.14 & 0.12 & 0.10 & -0.04 & -0.02 & 0.22 & 0.15 \\
\hline 1992 & 0.13 & 0.12 & 0.11 & 0.09 & -0.02 & -0.02 & 0.20 & 0.13 \\
\hline 1993 & 0.11 & 0.09 & 0.10 & 0.07 & -0.03 & -0.02 & 0.18 & 0.11 \\
\hline 1994 & 0.11 & 0.09 & 0.09 & 0.07 & -0.01 & 0.00 & 0.16 & 0.10 \\
\hline 1995 & 0.10 & 0.09 & 0.09 & 0.07 & -0.01 & 0.00 & 0.16 & 0.10 \\
\hline 1996 & 0.10 & 0.09 & 0.09 & 0.07 & -0.01 & -0.01 & 0.15 & 0.10 \\
\hline 1997 & 0.09 & 0.08 & 0.08 & 0.07 & -0.01 & 0.00 & 0.15 & 0.10 \\
\hline \multirow[t]{4}{*}{1998} & 0.10 & 0.09 & 0.09 & 0.07 & -0.01 & 0.00 & 0.15 & 0.10 \\
\hline & \multicolumn{4}{|c|}{ Apparent user cost of capital } & \multicolumn{4}{|c|}{$\begin{array}{l}\text { Apparent user cost of capital growth } \\
\text { rate }\end{array}$} \\
\hline & \multicolumn{2}{|c|}{ median } & \multicolumn{2}{|c|}{ MAD } & \multicolumn{2}{|c|}{ median } & \multicolumn{2}{|c|}{ MAD } \\
\hline & $\Pi \max$ & final & $\Pi \max$ & final & $\Pi \max$ & final & $\Pi \max$ & final \\
\hline 1991 & -1.84 & -1.84 & 0.42 & 0.34 & 0.10 & 0.09 & 0.41 & 0.36 \\
\hline 1992 & -1.86 & -1.84 & 0.42 & 0.34 & 0.05 & 0.04 & 0.25 & 0.22 \\
\hline 1993 & -1.76 & -1.74 & 0.38 & 0.31 & 0.14 & 0.13 & 0.24 & 0.21 \\
\hline 1994 & -1.76 & -1.74 & 0.35 & 0.28 & 0.08 & 0.03 & 0.23 & 0.20 \\
\hline 1995 & -1.70 & -1.70 & 0.35 & 0.27 & 0.09 & 0.07 & 0.16 & 0.14 \\
\hline 1996 & -1.81 & -1.81 & 0.40 & 0.33 & -0.07 & -0.08 & 0.29 & 0.28 \\
\hline 1997 & -1.77 & -1.81 & 0.38 & 0.32 & 0.07 & 0.06 & 0.19 & 0.19 \\
\hline \multirow[t]{4}{*}{1998} & -1.89 & -1.97 & 0.41 & 0.33 & -0.13 & -0.15 & 0.19 & 0.18 \\
\hline & \multicolumn{4}{|c|}{ Value added } & \multicolumn{4}{|c|}{ Value added growth } \\
\hline & \multicolumn{2}{|c|}{ median } & \multicolumn{2}{|c|}{ MAD } & \multicolumn{2}{|c|}{ median } & \multicolumn{2}{|c|}{ MAD } \\
\hline & $\Pi \max$ & final & $\Pi \max$ & final & $\Pi \max$ & final & $\Pi \max$ & final \\
\hline 1991 & 11.94 & 12.76 & 0.93 & 0.93 & 0.03 & 0.01 & 0.15 & 0.11 \\
\hline 1992 & 11.86 & 12.67 & 0.92 & 0.93 & 0.01 & 0.00 & 0.15 & 0.11 \\
\hline 1993 & 11.77 & 12.52 & 0.91 & 0.92 & -0.01 & -0.02 & 0.16 & 0.12 \\
\hline 1994 & 11.73 & 12.47 & 0.90 & 0.92 & 0.02 & 0.01 & 0.15 & 0.11 \\
\hline 1995 & 11.70 & 12.41 & 0.89 & 0.92 & 0.02 & 0.00 & 0.15 & 0.11 \\
\hline 1996 & 11.47 & 12.19 & 1.01 & 1.03 & -0.14 & -0.14 & 0.24 & 0.18 \\
\hline 1997 & 11.42 & 12.09 & 1.04 & 1.05 & 0.00 & -0.01 & 0.20 & 0.15 \\
\hline \multirow[t]{4}{*}{1998} & 11.38 & 12.04 & 1.04 & 1.05 & 0.02 & 0.01 & 0.19 & 0.14 \\
\hline & \multicolumn{4}{|c|}{ Cash flow } & \multicolumn{4}{|c|}{ Cash flow growth } \\
\hline & med & & MA & & med & & $\overline{\mathrm{M} A}$ & \\
\hline & $\Pi \max$ & final & $\Pi \max$ & final & $\Pi \max$ & final & $\Pi \max$ & final \\
\hline 1991 & 0.28 & 0.24 & 0.18 & 0.12 & -0.05 & 0.39 & 0.16 & 0.10 \\
\hline 1992 & 0.25 & 0.21 & 0.17 & 0.10 & -0.05 & 0.36 & 0.15 & 0.09 \\
\hline 1993 & 0.22 & 0.18 & 0.15 & 0.09 & -0.05 & 0.33 & 0.14 & 0.08 \\
\hline 1994 & 0.22 & 0.18 & 0.15 & 0.09 & -0.02 & 0.30 & 0.13 & 0.08 \\
\hline 1995 & 0.21 & 0.18 & 0.15 & 0.09 & -0.02 & 0.28 & 0.12 & 0.07 \\
\hline 1996 & 0.20 & 0.17 & 0.14 & 0.09 & -0.02 & 0.28 & 0.11 & 0.07 \\
\hline 1997 & 0.21 & 0.18 & 0.14 & 0.09 & -0.01 & 0.28 & 0.11 & 0.07 \\
\hline 1998 & 0.21 & 0.18 & 0.14 & 0.09 & -0.01 & 0.31 & 0.11 & 0.07 \\
\hline
\end{tabular}

$\Pi$ max refers to the sample profit-maximising firms 


\section{A2. Construction of the variables}

We define the variables as follows:

- The computation of the capital stock is based on the perpetual inventory method, i.e., applying the following formula

(a.1) $\quad \mathrm{P}_{\mathrm{st}}^{\mathrm{I}} \mathrm{K}_{\mathrm{it}}=\left(1-\delta_{\mathrm{i}}\right) \mathrm{P}_{\text {st- } 1}^{\mathrm{I}} \mathrm{K}_{\mathrm{it}-1}\left(\mathrm{P}_{\mathrm{st}}^{\mathrm{I}} / \mathrm{P}_{\mathrm{st}-1}^{\mathrm{I}}\right)+\mathrm{P}_{\mathrm{st}}^{\mathrm{I}} \mathrm{I}_{\mathrm{it}}$

with $\mathrm{K}_{\mathrm{it}}$ representing the real capital stock, $\mathrm{P}_{\mathrm{st}}^{\mathrm{I}}$ the sector-specific deflator on gross capital formation and $\delta_{\mathrm{i}}$ the firm-specific depreciation rate ${ }^{26}$.

- The firm-specific depreciation rate was estimated as the median depreciation expenditures on capital, over the years in which the firm exists.

- The user cost of capital takes into account forward-looking expectations. It is based on the apparent interest rate faced by the firm, $\mathrm{i}_{\mathrm{it}}{ }^{27}$. We do not incorporate taxes in the definition of the user cost, although we do subtract interest subsidies from debt charges in the definition of the apparent user cost. Our expression for the user cost is daily standard:

$$
\mathrm{UCC}_{\mathrm{it}}=\frac{\mathrm{P}_{\mathrm{st}}^{\mathrm{I}}}{\mathrm{P}_{\mathrm{st}}}\left[\mathrm{i}_{\mathrm{it}}+\delta_{\mathrm{i}}-\left(1-\delta_{\mathrm{i}}\right) \frac{\Delta \mathrm{P}_{\mathrm{st}+1}^{\mathrm{I}}}{\mathrm{P}_{\mathrm{st}}^{\mathrm{I}}}\right]
$$

where $\mathrm{P}_{\text {st }}^{\mathrm{I}}$ is the sector-specific deflator on gross capital formation and $\mathrm{P}_{\mathrm{st}}$ is the sector-specific value-added price.

- Cash flow is defined as net profits plus depreciation ${ }^{28}$.

- Value added is expressed in real terms.

- We use 2-digit NACE codes for investment and value-added prices aggregated for 23 sectors.

Table A.6 summarises these variables for large and small firms. Large firms experienced a smaller decline in value added, face a lower user cost and have a higher cash flow ratio. Small firms have a more volatile investment rate.

26 The capital stock at time $\mathrm{t}$ results from investments undertaken over different periods. Therefore, using current investment prices to deflate the nominal capital stock is not correct. The perpetual inventory method allows to circumvent this problem, except for the initial stock, $\mathrm{K}_{\mathrm{i} 0}$.

27 For small firms, we consider the ratio of financial charges minus interest subsidies over debt, rather than the ratio of debt charges minus interest subsidies over debt, because small firms do not have to provide this information.

Some authors rely on an estimate of the firm-specific interest rate based on the market short- and longterm rates and the debt structure of the firm, which may be appropriate for capturing the marginal user cost, the cost of a new investment project. However, this indicator ignores all firm-specific differences in the cost of credit. Such differences may arise, for example, because firms are in a riskier sector, or because firms are young, or because they have weak bank relationships.

28 Again the definition differs for small and large firms according to data availability. 
Table A.6: Summary statistics over the final sample

\begin{tabular}{lrrrrrrr}
\hline large firms & mean & std. dev. & maximum & $75 \%$ & median & $25 \%$ & minimum \\
\hline $\mathrm{I} / \mathrm{K}$ & 0.169 & 0.233 & 3.007 & 0.208 & 0.107 & 0.045 & -0.266 \\
$\Delta \log$ VA & -0.013 & 0.323 & 5.708 & 0.106 & 0.004 & -0.105 & -7.984 \\
$\Delta \log$ UCC & -0.009 & 0.559 & 3.498 & 0.232 & 0.011 & -0.263 & -3.239 \\
$\mathrm{CF} / \mathrm{K}$ & 0.346 & 0.657 & 15.834 & 0.379 & 0.216 & 0.124 & -2.263 \\
$\log$ VA & 14.692 & 1.280 & 21.661 & 15.359 & 14.576 & 13.907 & 6.419 \\
$\log$ UCC & -2.006 & 0.567 & 1.144 & -1.685 & -1.976 & -2.312 & -4.886 \\
\hline small firms & mean & std. dev. & maximum & $75 \%$ & median & $25 \%$ & minimum \\
\hline $\mathrm{I} / \mathrm{K}$ & 0.194 & 0.344 & 5.750 & 0.227 & 0.093 & 0.029 & -0.287 \\
$\Delta \log$ VA & -0.056 & 0.413 & 5.430 & 0.111 & -0.018 & -0.170 & -8.157 \\
$\Delta \log$ UCC & -0.007 & 0.474 & 3.040 & 0.213 & 0.009 & -0.227 & -2.662 \\
CF/K & 0.235 & 0.283 & 5.239 & 0.298 & 0.181 & 0.102 & -1.044 \\
$\log$ VA & 11.991 & 1.224 & 16.266 & 12.861 & 12.048 & 11.208 & 3.168 \\
$\log$ UCC & -1.777 & 0.558 & 0.857 & -1.471 & -1.777 & -2.106 & -4.348 \\
\hline
\end{tabular}




\section{Appendix B: Robustness with respect to alternative trimming procedure}

In this appendix we trim our sample using a different procedure for deleting outliers. As before, we trim the same variables as previously, year by year. In order to define the trimming threshold we rely on the median absolute deviation from the median. More precisely, for each variable, y, we consider only the firm-year observations whose deviation from the median does not exceed six times the median of their deviation from the median:

(b.1) $\quad\left|y_{\text {it }}-\operatorname{median}\left(\mathrm{y}_{\text {it }}\right)\right|<6 . \operatorname{median}\left[\left\lfloor\mathrm{y}_{\text {it }}-\operatorname{median}\left(\mathrm{y}_{\text {it }}\right) \mid\right]\right.$

This procedure is more robust to outliers and yields a more symmetric distribution than the interpercentile range. The value of 6 is ad hoc and it may be regarded as too conservative since it yields a sample which is half the interpercentile range. Thus the aim of this section is to check the robustness of our conclusions with respect to a more robust and more conservative trimming procedure.

The results are presented below. Table B.1 considers all sectors combined and distinguishes between small and large firms. Comparison with Table 3 confirms our previous findings that the total effect of past investment is negative for small firms and that small firms have a higher long-run elasticity with respect to cash flow.

Tables B. 2 and B. 3 make comparisons with Tables 4 and 5 and distinguish between both (broad) sectors and size. The results confirm our previous findings, i.e. (1) the sum of the coefficients on past investment rate is more negative for small firms, (2) the long-run elasticity of investment to user cost fluctuations is greater for small firms, and nonsignificant for small services, (3) the long-run elasticity of investment to value added fluctuations is higher for large firms, (4) the long-run cash flow sensitivity is higher for small firms, (5) construction is more sensitive to user cost fluctuations than other sectors, and (6) manufacturing is more sensitive to value added fluctuations than other sectors. 
Table B.1: ADL(4) model for large and small firms for the sample trimmed according to the MAD criterion (b.1)

\begin{tabular}{|c|c|c|c|c|c|c|}
\hline & \multicolumn{2}{|c|}{ all firms } & \multicolumn{2}{|c|}{ large firms } & \multicolumn{2}{|c|}{ small firms } \\
\hline & coef & t-stat & coef & t-stat & coef & t-stat \\
\hline$\overline{\mathrm{I}_{\mathrm{t}-1} / \mathrm{K}_{\mathrm{t}-2}}$ & 0.011 & 0.642 & $0.043^{* *}$ & 2.491 & 0.008 & -0.682 \\
\hline $\mathrm{I}_{\mathrm{t}-2} / \mathrm{K}_{\mathrm{t}-3}$ & $0.006^{* * *}$ & -3.012 & $-0.061 * * *$ & -4.428 & $-0.020 * * *$ & -2.748 \\
\hline $\mathrm{I}_{\mathrm{t}-3} / \mathrm{K}_{\mathrm{t}-4}$ & $0.006 * * *$ & -2.823 & $-0.029 * *$ & -2.350 & $-0.018 * * *$ & -2.686 \\
\hline $\mathrm{I}_{\mathrm{t}-4} / \mathrm{K}_{\mathrm{t}-5}$ & 0.006 & -0.159 & $-0.064 * * *$ & -5.560 & 0.007 & 1.023 \\
\hline$\Sigma\left(I_{t-j} / K_{t-j-1}\right)$ & $0.030 * * *$ & 2.975 & $0.110^{* *}$ & -2.395 & $0.039 * * *$ & -2.790 \\
\hline$\Delta \log \left(\mathrm{UCC}_{\mathrm{t}}\right)$ & 0.006 & 0.096 & -0.003 & -0.411 & 0.002 & -0.298 \\
\hline$\Delta \log \left(\mathrm{UCC}_{\mathrm{t}-1}\right)$ & 0.003 & -1.382 & $-0.012 * * *$ & -2.668 & 0.005 & -1.429 \\
\hline$\Delta \log \left(\mathrm{UCC}_{\mathrm{t}-2}\right)$ & 0.003 & -0.820 & $0.010 * *$ & -2.347 & 0.002 & -0.714 \\
\hline$\Delta \log \left(\mathrm{UCC}_{\mathrm{t}-3}\right)$ & $0.002 * *$ & -2.044 & $-0.008 * *$ & -2.318 & $0.005 * *$ & -2.019 \\
\hline$\Delta \log \left(\mathrm{UCC}_{\mathrm{t}-4}\right)$ & $0.002^{*}$ & -1.839 & $-0.006 * *$ & -2.065 & 0.003 & -1.588 \\
\hline$\Sigma \Delta \log \left(U C C_{t-j}\right)$ & 0.015 & 0.256 & $-0.038 * * *$ & -3.827 & $0.018^{*}$ & -1.953 \\
\hline Long-run elasticity & 0.016 & & -0.034 & & 0.017 & \\
\hline$\Delta \log \left(\mathrm{VA}_{\mathrm{t}}\right)$ & 0.025 & 0.189 & $0.067^{* *}$ & 2.475 & 0.028 & 1.075 \\
\hline$\Delta \log \left(\mathrm{VA}_{\mathrm{t}-1}\right)$ & $0.009 * *$ & 2.112 & $0.038 * * *$ & 3.275 & $0.023^{* *}$ & 2.291 \\
\hline$\Delta \log \left(\mathrm{VA}_{\mathrm{t}-2}\right)$ & 0.007 & 1.387 & $0.024 * *$ & 2.466 & 0.011 & 1.375 \\
\hline$\Delta \log \left(\mathrm{VA}_{\mathrm{t}-3}\right)$ & 0.006 & 1.124 & 0.010 & 1.144 & 0.008 & 1.192 \\
\hline$\Delta \log \left(\mathrm{VA}_{\mathrm{t}-4}\right)$ & 0.004 & 1.004 & 0.002 & 0.291 & 0.005 & 1.038 \\
\hline$\Sigma \Delta \log \left(V A_{t-j}\right)$ & 0.051 & 1.235 & $0.140 * * *$ & 2.700 & 0.075 & 1.636 \\
\hline Long-run elasticity & 0.052 & & 0.126 & & 0.072 & \\
\hline $\mathrm{CASH}_{\mathrm{t}}$ & $0.086^{* * *}$ & 3.942 & 0.102 & 1.587 & $0.347 * * *$ & 3.804 \\
\hline $\mathrm{CASH}_{\mathrm{t}-1}$ & 0.031 & -0.343 & 0.013 & 0.523 & 0.001 & 0.023 \\
\hline $\mathrm{CASH}_{\mathrm{t}-2}$ & 0.011 & -0.116 & 0.004 & 0.299 & 0.001 & -0.098 \\
\hline $\mathrm{CASH}_{\mathrm{t}-3}$ & 0.008 & 0.576 & -0.014 & -1.164 & 0.012 & 1.234 \\
\hline $\mathrm{CASH}_{\mathrm{t}-4}$ & 0.010 & 0.899 & 0.013 & 0.879 & 0.013 & 1.097 \\
\hline $\begin{array}{l}\Sigma C A S H_{t-j} \\
\text { Long-run elasticity }\end{array}$ & $0.146^{* * *}$ & 2.974 & 0.118 & 2.564 & 0.371 & 7.281 \\
\hline & statistic & p-value & statistic & p-value & statistic & p-value \\
\hline$\overline{\mathrm{nb}, \mathrm{obs}}$ & 75444 & & 12641 & & 62267 & \\
\hline $\mathrm{nb}$, firms & 14876 & & 2393 & & 12514 & \\
\hline Sargan & 174.775 & 0.002 & 133.433 & 0.286 & 181.576 & 0.001 \\
\hline $\mathrm{m} 1$ & |-63.352 & 0.000 & |-25.835 & 0.000 & -55.064 & 0.000 \\
\hline $\mathrm{m} 2$ & 0.652 & 0.514 & -1.145 & 0.252 & 1.177 & 0.239 \\
\hline
\end{tabular}

2nd step GMM Arellano-Bond estimates of the investment equation (4) over 1991-1998 the constant and time dummies are not shown

* significant at the $10 \%$ level; ** significant at the $5 \%$ level; *** significant at the $1 \%$ level 
Table B.2: ADL(4) model of investment for large firms for the sample trimmed according to the MAD criterion (b.1):sector estimates

\begin{tabular}{|c|c|c|c|c|c|c|}
\hline & \multicolumn{2}{|c|}{ manufacturing } & \multicolumn{2}{|c|}{ construction } & \multicolumn{2}{|l|}{ services } \\
\hline & coef & t-stat & coef & t-stat & coef & t-stat \\
\hline$\overline{\mathrm{I}_{\mathrm{t}-1} / \mathrm{K}_{\mathrm{t}-2}}$ & 0.011 & 0.642 & $0.043^{* *}$ & 2.491 & -0.008 & -0.682 \\
\hline $\mathrm{I}_{\mathrm{t}-2} / \mathrm{K}_{\mathrm{t}-3}$ & $0.006 * * *$ & -3.012 & $-0.061 * * *$ & -4.428 & $-0.020 * * *$ & -2.748 \\
\hline $\mathrm{I}_{\mathrm{t}-3} / \mathrm{K}_{\mathrm{t}-4}$ & $0.006^{* * *}$ & -2.823 & $-0.029 * *$ & -2.350 & $-0.018 * * *$ & -2.686 \\
\hline $\mathrm{I}_{\mathrm{t}-4} / \mathrm{K}_{\mathrm{t}-5}$ & 0.006 & -0.159 & $-0.064 * * *$ & -5.560 & 0.007 & 1.023 \\
\hline$\Sigma\left(I_{t-j} / K_{t-j-1}\right)$ & $0.030 * * *$ & 2.975 & $0.110 * *$ & -2.395 & $-0.039 * * *$ & -2.790 \\
\hline$\Delta \log \left(\mathrm{UCC}_{\mathrm{t}}\right)$ & 0.006 & 0.096 & -0.003 & -0.411 & -0.002 & -0.298 \\
\hline$\Delta \log \left(\mathrm{UCC}_{\mathrm{t}-1}\right)$ & 0.003 & -1.382 & $-0.012 * * *$ & -2.668 & -0.005 & -1.429 \\
\hline$\Delta \log \left(\mathrm{UCC}_{\mathrm{t}-2}\right)$ & 0.003 & -0.820 & $-0.010 * *$ & -2.347 & -0.002 & -0.714 \\
\hline$\Delta \log \left(\mathrm{UCC}_{\mathrm{t}-3}\right)$ & $0.002 * *$ & -2.044 & $-0.008 * *$ & -2.318 & $-0.005 * *$ & -2.019 \\
\hline$\Delta \log \left(\mathrm{UCC}_{\mathrm{t}-4}\right)$ & $0.002 *$ & -1.839 & $-0.006 * *$ & -2.065 & -0.003 & -1.588 \\
\hline$\Sigma \Delta \log \left(U C C_{t-j}\right)$ & 0.015 & 0.256 & $-0.038 * * *$ & -3.827 & $0.018^{*}$ & -1.953 \\
\hline Long-run elasticity & 0.016 & & -0.034 & & -0.017 & \\
\hline$\Delta \log \left(\mathrm{VA}_{\mathrm{t}}\right)$ & 0.025 & 0.189 & $0.067^{* *}$ & 2.475 & 0.028 & 1.075 \\
\hline$\Delta \log \left(\mathrm{VA}_{\mathrm{t}-1}\right)$ & $0.009 * *$ & 2.112 & $0.038 * * *$ & 3.275 & $0.023 * *$ & 2.291 \\
\hline$\Delta \log \left(\mathrm{VA}_{\mathrm{t}-2}\right)$ & 0.007 & 1.387 & $0.024 * *$ & 2.466 & 0.011 & 1.375 \\
\hline$\Delta \log \left(\mathrm{VA}_{\mathrm{t}-3}\right)$ & 0.006 & 1.124 & 0.010 & 1.144 & 0.008 & 1.192 \\
\hline$\Delta \log \left(\mathrm{VA}_{\mathrm{t}-4}\right)$ & 0.004 & 1.004 & 0.002 & 0.291 & 0.005 & 1.038 \\
\hline$\Sigma \Delta \log \left(V A_{t-j}\right)$ & 0.051 & 1.235 & $0.140^{* * *}$ & 2.700 & 0.075 & 1.636 \\
\hline Long-run elasticity & 0.052 & & 0.126 & & 0.072 & \\
\hline $\mathrm{CASH}_{\mathrm{t}}$ & $0.086^{* * *}$ & 3.942 & 0.102 & 1.587 & $0.347 * * *$ & 3.804 \\
\hline $\mathrm{CASH}_{\mathrm{t}-1}$ & 0.031 & -0.343 & 0.013 & 0.523 & 0.001 & 0.023 \\
\hline $\mathrm{CASH}_{\mathrm{t}-2}$ & 0.011 & -0.116 & 0.004 & 0.299 & -0.001 & -0.098 \\
\hline $\mathrm{CASH}_{\mathrm{t}-3}$ & 0.008 & 0.576 & -0.014 & -1.164 & 0.012 & 1.234 \\
\hline $\mathrm{CASH}_{\mathrm{t}-4}$ & 0.010 & 0.899 & 0.013 & 0.879 & 0.013 & 1.097 \\
\hline$\Sigma C A S H_{t-j}$ & $0.146^{* * *}$ & 2.974 & 0.118 & 2.564 & 0.371 & 7.281 \\
\hline \multirow[t]{2}{*}{ Long-run elasticity } & 0.150 & & 0.106 & & 0.357 & \\
\hline & statistic & $\mathrm{p}$-value & statistic & p-value & statistic & $\mathrm{p}$-value \\
\hline No. of obs & 3112 & & 1532 & & 7951 & \\
\hline No. of firms & 628 & & 271 & & 1485 & \\
\hline Sargan & 124.073 & 0.507 & 133.192 & 0.291 & 129.961 & 0.363 \\
\hline Wald - lag 4 & 2.831 & 0.586 & 41.927 & 0.000 & 26.396 & 0.000 \\
\hline $\mathrm{m} 1$ & -12.148 & 0.000 & -9.164 & 0.000 & -20.433 & 0.000 \\
\hline $\mathrm{m} 2$ & 1.7 & 0.089 & -0.712 & 0.476 & -2.423 & 0.015 \\
\hline
\end{tabular}


Table B.3: ADL(4) model of investment for small firms for the sample trimmed according to the MAD criterion (b.1): sector estimates

\begin{tabular}{|c|c|c|c|c|c|c|}
\hline & \multicolumn{2}{|c|}{ manufacturing } & \multicolumn{2}{|c|}{ construction } & \multicolumn{2}{|l|}{ services } \\
\hline & coef & t-stat & coef & t-stat & coef & t-stat \\
\hline $\mathrm{I}_{\mathrm{t}-1} / \mathrm{K}_{\mathrm{t}-2}$ & 0.020 & 0.977 & $-0.077 * * *$ & -5.025 & 0.013 & -0.912 \\
\hline $\mathrm{I}_{\mathrm{t}-2} / \mathrm{K}_{\mathrm{t}-3}$ & $-0.037 * *$ & -2.057 & $-0.036 * * *$ & -2.849 & $-0.025 * * *$ & -2.849 \\
\hline $\mathrm{I}_{\mathrm{t}-3} / \mathrm{K}_{\mathrm{t}-4}$ & $-0.037 * *$ & -1.994 & -0.016 & -1.339 & $-0.022 * * *$ & -2.657 \\
\hline $\mathrm{I}_{\mathrm{t}-4} / \mathrm{K}_{\mathrm{t}-5}$ & -0.001 & -0.081 & 0.010 & 0.913 & 0.002 & 0.296 \\
\hline$\Sigma\left(I_{t-j} / K_{t-j-1}\right)$ & -0.056 & -0.941 & -0.119 & -1.617 & $-0.058 * *$ & -2.189 \\
\hline$\Delta \log \left(\mathrm{UCC}_{\mathrm{t}}\right)$ & $-0.039 * * *$ & -2.660 & $-0.081 * * *$ & -3.366 & 0.006 & 0.875 \\
\hline$\Delta \log \left(\mathrm{UCC}_{\mathrm{t}-1}\right)$ & $-0.021 * *$ & -2.327 & $-0.026 * *$ & -2.191 & -0.003 & -0.885 \\
\hline$\Delta \log \left(\mathrm{UCC}_{\mathrm{t}-2}\right)$ & $-0.015^{*}$ & -1.740 & - 0.005 & -0.513 & -0.003 & -0.786 \\
\hline$\Delta \log \left(\mathrm{UCC}_{\mathrm{t}-3}\right)$ & -0.010 & -1.303 & -0.005 & -0.654 & $-0.005^{*}$ & -1.740 \\
\hline$\Delta \log \left(\mathrm{UCC}_{\mathrm{t}-4}\right)$ & -0.003 & -0.428 & -0.002 & -0.296 & $-0.005 * *$ & -1.989 \\
\hline$\Sigma \Delta \log \left(U C C_{t-j}\right)$ & $-0.087 * *$ & -2.411 & $-0.118^{* *}$ & -2.234 & -0.010 & -1.027 \\
\hline Long-run elasticity & -0.082 & & -0.106 & & -0.009 & \\
\hline$\Delta \log \left(\mathrm{VA}_{\mathrm{t}}\right)$ & 0.030 & 1.386 & 0.038 & 1.197 & 0.025 & 0.854 \\
\hline$\Delta \log \left(\mathrm{VA}_{\mathrm{t}-1}\right)$ & $0.065 * * *$ & 3.304 & 0.022 & 1.528 & $0.021^{*}$ & 1.813 \\
\hline$\Delta \log \left(\mathrm{VA}_{\mathrm{t}-2}\right)$ & $0.044 * *$ & 2.024 & 0.004 & 0.333 & 0.009 & 0.971 \\
\hline$\Delta \log \left(\mathrm{VA}_{\mathrm{t}-3}\right)$ & 0.002 & 0.084 & 0.000 & 0.027 & 0.010 & 1.181 \\
\hline$\Delta \log \left(\mathrm{VA}_{\mathrm{t}-4}\right)$ & - 0.006 & -0.492 & -0.006 & -0.651 & 0.006 & 1.147 \\
\hline$\Sigma \Delta \log \left(V A_{t-j}\right)$ & $0.133^{*}$ & 1.817 & 0.059 & 0.908 & 0.071 & 1.262 \\
\hline Long-run elasticity & 0.126 & & 0.053 & & 0.067 & \\
\hline $\mathrm{CASH}_{\mathrm{t}}$ & $0.234 * * *$ & 2.922 & 0.134 & 1.511 & $0.279 * * *$ & 2.642 \\
\hline $\mathrm{CASH}_{\mathrm{t}-1}$ & 0.005 & -0.095 & $0.053^{*}$ & 1.801 & 0.026 & 0.654 \\
\hline $\mathrm{CASH}_{\mathrm{t}-2}$ & -0.003 & -0.090 & -0.012 & -0.635 & 0.017 & 1.185 \\
\hline $\mathrm{CASH}_{\mathrm{t}-3}$ & $0.085^{* * *}$ & 3.074 & -0.011 & -0.695 & 0.014 & 1.174 \\
\hline $\mathrm{CASH}_{\mathrm{t}-4}$ & -0.014 & -0.438 & 0.019 & 1.022 & 0.011 & 0.727 \\
\hline$\Sigma C A S H_{t-j}$ & $0.298 * * *$ & 4.126 & $0.184 * * *$ & 2.708 & $0.347^{* * * *}$ & 5.550 \\
\hline \multirow[t]{2}{*}{ Long-run elasticity } & 0.282 & & 0.164 & & 0.328 & \\
\hline & statistic & $\mathrm{p}$-value & statistic & $\mathrm{p}$-value & statistic & $\mathrm{p}$-value \\
\hline No. of obs & 5888 & & 12999 & & 43281 & \\
\hline No. of firms & 1272 & & 2488 & & 8732 & \\
\hline Sargan & 106.894 & 0.878 & 132.184 & 0.313 & 172.055 & 0.003 \\
\hline Wald - lag 4 & 0.796 & 0.939 & 2.645 & 0.619 & 6.367 & 0.173 \\
\hline $\mathrm{m} 1$ & -18.282 & 0.000 & -26.305 & 0.000 & -47.384 & 0.000 \\
\hline $\mathrm{m} 2$ & 2.299 & 0.022 & 0.055 & 0.956 & 1.182 & 0.237 \\
\hline
\end{tabular}

2nd step GMM Arellano-Bond estimates of the investment equation (4) over 1991-1998 the constant and time dummies are not shown

* significant at the $10 \%$ level; ** significant at the $5 \%$ level; *** significant at the $1 \%$ level 